https:/ / doi.org/10.18485/iipe_nsail.2020.ch10

Vanja PAVIĆEVIĆ 1

\title{
UTICAJ INVESTITORA KAO NEDRŽAVNIH AKTERA U MEĐUNARODNOM PRAVU
}

Apstrakt: Međunarodnopravni poredak u XXI veku sve više podseća na kaleidoskop sačinjen od mnoštva nedržavnih aktera, koji različitim aktivnostima utiču na dinamiku međunarodnih odnosa. Počev od položaja nevladinih organizacija, pojedinca ali i manjina - urođeničkih naroda, preko terorističkih grupa, sve do multinacionalnih kompanija, ne postoji nijedna oblast međunarodnog prava u kojoj nedržavni akteri, $u$ većoj ili manjoj meri, nisu uticali na stvaranje, razvoj ili način primene pravnih normi. Ipak, čini se da je uloga nedržavnih aktera najvidljivija u oblasti međunarodnog investicionog prava, što se ogleda kroz rastući uticaj stranih investitora. Njihov položaj izaziva mnoštvo kontroverzi u međunarodnom pravu, pre svega zbog specifičnog mehanizma rešavanja sporova koji investitoru omogućava da podnese tužbu izabranom arbitražnom tribunalu direktno protiv države domaćina. Na taj način, uprkos formalnom nedostatku svojstva subjekta $\mathrm{u}$ međunarodnom pravu, investitor uspeva da svoju poziciju u konkretnom sporu faktički izjednači sa državom. Dodatno, nedovoljno rasvetljena pravna priroda tzv. „internacionalizovanih ugovora“ pruža mogućnosti za različita tumačenja - mogu li investitori, na osnovu takvih ugovora, uživati ne samo status objekta, već u određenom stepenu i subjekta međunarodnog prava? U ovom radu autor će ispitati izvore međunarodnog investicionog prava,

\footnotetext{
${ }^{1}$ Doktorand Pravnog fakulteta Univerziteta u Beogradu i istraživač pripravnik $u$ Institutu za međunarodnu politiku i privredu, Beograd, e-mail: vanja.pavicevic@diplomacy.bg.ac.rs

Rad je nastao u okviru projekta „Srbija i izazovi u međunarodnim odnosima 2020. godine" , koji finansira Ministarstvo prosvete, nauke i tehnološkog razvoja Republike Srbije, a realizuje Institut za međunarodnu politiku i privredu tokom 2020. godine.
} 
položaj investitora prilikom rešavanja investicionih sporova, kao i eventualnu razliku između formalnog i faktičkog položaja koji investitori uživaju u međunarodnopravnom poretku.

Ključne reči: nedržavni akteri, investitori, multinacionalne kompanije, međunarodnopravni subjektivitet, arbitražno rešavanje sporova, investicioni sporovi, međunarodno investiciono pravo

\section{UVODNE NAPOMENE O MEĐUNARODNOPRAVNOM SUBJEKTIVITETU}

Međunarodnopravni poredak obuhvata raznovrsne aktere, čija priroda i pravni položaj mogu biti posve različiti, a koji svojim učešćem u pravnom životu pokreću točkove međunarodnih odnosa. No, učešće u pravnom životu, $\mathrm{s}$ jedne strane, i međunarodnopravni subjektivitet, $\mathrm{s}$ druge, predstavljaju dva odvojena koncepta. ${ }^{2}$ Prosto učešće u pravnom životu ne predstavlja pravni koncept ${ }^{3}$ te stoga ne zahteva posedovanje međunarodnopravnog subjektiviteta. Ono podrazumeva niz različitih aktivnosti kroz koje nedržavni akteri mogu biti vidljivi na međunarodnoj sceni. Međutim, kada je reč o međunarodnopravnom subjektivitetu, situacija je posve složenija. U teoriji međunarodnog prava ne postoji univerzalno prihvaćena i identična definicija međunarodnopravne ličnosti, odnosno međunarodnopravnog subjektiviteta. ${ }^{4}$ Subjektivitet $\mathrm{u}$ međunarodnom pravu može naizgled biti okarakterisan kao teorijski problem, no, on ima značajne praktične ali i političke posledice. Njegova sadržina čak i danas rađa određene nedoumice, ostajući nedovoljno

${ }^{2}$ Malcolm N. Shaw, International Law, Cambridge University Press, USA, New York, Sixth edition, 2008, p. 264.

${ }^{3}$ Jean d'Aspremont, "Non-state actors in International Law: Oscillating Between Concepts and Dynamics" in Participants in the International Legal System - Multiple Perspectives on non-state actors in International Law, (ed.) Jean d'Aspremont, Routledge Research in International Law, London, 2011, p. 3.

${ }^{4}$ U ovom radu termini međunarodnopravnog subjektiviteta i međunarodnopravne ličnosti koristiće se naizmenično, budući da suštinski označavaju istu sposobnost da se bude nosilac međunarodnih prava i obaveza. Tako i Klabers: „,Međunarodno pravo nema formalnih kriterijuma za prijem u'status subjekta', ili, što se u praksi svodi na isto, međunarodnu pravnu ličnost". Jan Klabbers, International Law, Cambridge University Press, UK, 2017, pp. 72-73. 
definisana i neprestano izazivana društvenim promenama. Uzrok ovakve formalne neodređenosti jeste posledica visoko izražene političke prirode ovog procesa. $^{5}$

Različiti autori doprineli su u pokušaju da se što preciznije semantički obuhvati međunarodnopravni subjektivitet. Tako Braunli (Brownlie) navodi nekoliko generalno priznatih pokazatelja pravne ličnosti: ugovorna sposobnost, mogućnost ostvarivanja prava putem diplomatskih ili drugih procedura, odgovornost za kršenje međunarodnog prava, privilegije i imunitete, dodajući kako nije neophodno da predmetni entitet poseduje sve navedene indicije. ${ }^{6}$ Drugi autori smatraju da je pravna ličnost, odnosno pravni subjektivitet sposobnost jednog entiteta da bude nosilac prava i obaveza u okviru datog pravnog sistema. ${ }^{7}$ D' Aspremon (Jean d'Aspremont) smatra da je ideja da se međunarodni subjektivitet može regulisati međunarodnim pravom ništa drugo do iluzija u koju naučnici često upadaju, ironično je nazivajući "Čudo iz Montevidea“, budući da je nemoguće zauzdati politički uticaj koji izvire iz čina priznanja države. ${ }^{8}$ Ističe se, takođe, da je subjekt prava osoba koja učestvuje, ili koja je sposobna da učestvuje u pravnim odnosima, ${ }^{9}$ što je veoma interesantno jer ovako generično postavljene definicije mogu obuhvatiti širok krug

\footnotetext{
${ }^{5}$ Jean d'Aspremont, "Non- state actors in International Law: Oscillating Between Concepts and Dynamics", op. cit., p. 2.

${ }^{6}$ Ian Brownlie, The Rule of Law in International Affairs - International Law at the Fiftieth Anniversary of the United Nations, (General Course on Public International Law delivered at the Hague Academy of International Law to commemorate the fiftieth anniversary of the foundation of the United Nations), Martinus Nijhoff Publishers, The Hague, 1998, p. 36.

${ }^{7}$ Davor Muhvic, "Legal Personality as a Theoretical Approach to Non-State Entities in International Law: The Example of Transnational Corporations", Pécs Journal of International and European Law, Centre for European Research and Education, 2017/I, p. 9.

${ }^{8}$ Sintagmom „Čudo iz Montevidea" autor aludira na Montevideo Konvenciju o pravima i dužnostima država iz 1933. godine, koja postavlja opšte kriterijume državnosti. Jean d'Aspremont, "Non- state actors in International Law: Oscillating Between Concepts and Dynamics", op. cit., p. 2.

${ }^{9}$ Christian N. Okeke, Controversial Subjects of Contemporary International Law - an examination of the new entitites of international law and their treaty-making capacity, Rotterdam University Press, 1973, p. 16.
} 
aktera. Već je poznato da države, kao originerni i potpuni subjekti međunarodnog prava, poseduju međunarodnopravni subjektivitet posedovanjem elemenata državnosti. Član 1 Montevideo konvencije o pravima i obavezama država iz 1933. godine navodi četiri elementa koje država, kao međunarodnopravna ličnost, mora da ispuni: stalnu populaciju, definisanu teritoriju, efektivnu vlast, kao i sposobnost da stupa u odnose sa drugim državama. ${ }^{10}$ Ipak, čini se da upliv političkog uticaja prilikom određivanja kriterijuma državnosti predstavlja teret koji se ne može izbeći, pogotovo imajući $u$ vidu sve brojnije slučajeve samoproklamovane nezavisnosti određenih entiteta. Stoga, čak i u slučaju izvornih i potpunih subjekata međunarodnog prava kao što su države, čini se da je definicija njihovog subjektiviteta podložna promenama. Kada je reč o međunarodnim organizacijama, još je $u$ prošlom veku Međunarodni sud pravde istakao, u svom čuvenom savetodavnom mišljenju povodom naknade štete pretrpljene u službi Ujedinjenih nacija, da „pravni subjekti u svakom pravnom sistemu nisu nužno identični po svojoj prirodi ili po opsegu svojih prava, te da njihova priroda zavisi od potreba zajednice" (prevod V.P.). ${ }^{11}$ Pomenutim mišljenjem potvrdio je status organizacije Ujedinjenih nacija kao potpunog subjekta međunarodnog prava, a time indirektno i popločao put postojanju subjektiviteta ostalih međuvladinih organizacija. Citirani odlomak postao je neka vrsta "magijske mantre", koja se izgovara svaki put prilikom suočavanja sa međunarodnopravnom ličnošću. ${ }^{12}$

Postoje mišljenja da, sudeći po savetodavnom mišljenju Suda, koje i dalje predstavlja najautoritativniji tekst u kontekstu međunarodno-

\footnotetext{
${ }^{10}$ Montevideo konvencija o pravima i dužnostima država, "Convention on Rights and Duties of States", Art. 1, dostupno na https://www.oas.org/juridico/ english/treaties/a-40.html, pristupljeno: 27.2.2020.

${ }^{11}$ Reparation for injuries suffered in the service of the United Nations, Advisory Opinion: ICJ, April 11th 1949, p. 178, dostupno na https://www.icj-cij.org/files/caserelated/4/004-19490411-ADV-01-00-EN.pdf, pristupljeno 27.2.2020. godine.

${ }^{12}$ Janne E. Nijman, "Non-state actors and the international rule of law: Revisiting the 'realist theory' of international legal personality", in Non-State Actor Dynamics in International Law, From Law-Takers to Law-Makers, (eds.) Math Noortmann, Cedric Ryngaertp, Ashate Publishing, 2010, p. 110.
} 
pravne ličnosti, odsustvo određenih elemenata pravne sposobnosti koju uživaju države kao tipični subjekti međunarodnog prava, ne prekludira proširenje predmetnog statusa na nedržavne entitete..$^{13}$ Stoga, pored država i međuvladinih organizacija, kao nespornih subjekata međunarodnog prava, važno je posvetiti pažnju i ostalim učesnicima međunarodnopravnog života. Da li se neki od njih mogu smatrati subjektom međunarodnog prava, makar u ograničenom smislu? Da li je moguće napraviti distinkciju između subjekata međunarodnog prava u užem smislu (entiteti čija prava i obaveze izviru iz opšteg međunarodnog prava), i subjekata međunarodnog prava u širem smislu (entiteta čija prava i obaveze izviru isključivo iz određene grane međunarodnog prava)? ${ }^{14}$ U pokušaju da se pruži odgovor, smatramo da je važno preispitati, ali možda i još važnije - izazvati određene zaključke koje nam doktrina nameće kao aksiome.

\section{PROLIFERACIJA NEDRŽAVNIH AKTERA - FRAGMENTACIJA PRAVNOG SUBJEKTIVITETA?}

Ekonomske i političke promene koje XXI vek neumorno rađa reflektuju se i na međunarodno pravo. Kao posledica sve složenijih međunarodnih odnosa, savremeno međunarodno pravo odlikuje se rastućom proliferacijom nedržavnih aktera. Postoji mnoštvo različitih definicija nedržavnih aktera, koje se suštinski mogu suziti na negativno određen pojam - „,bilo koji entitet koji nije država u smislu međunarodnog prava“ ${ }^{15}$ Međutim, takvi nedržavni akteri uključeni su u velike i složene međunarodne operacije, neretko sa vladama različitih država i javnim finansijskim agencijama, stoga pitanje njihovog međunarodnog statusa ne može biti okončano samo negativnom definicijom. ${ }^{16}$

${ }^{13}$ Davor Muhvic, "Legal Personality as a Theoretical Approach to Non-State Entities in International Law: The Example of Transnational Corporations", op. cit., p. 15.

${ }^{14}$ Ibid., p. 17.

${ }^{15}$ Janne E. Nijman, "Non-state actors and the international rule of law: Revisiting the 'realist theory' of international legal personality", op. cit., p. 6. 
Komitet za nedržavne aktere Udruženja za međunarodno pravo definiše nedržavne aktere kao „međunarodno pravno prepoznate i organizovane entitete ${ }^{\prime 17}$ Ova definicija je uža od opšteg shvatanja, budući da zahteva pravno organizovanu strukturu, te da su, na primer, urođenički narodi u ovoj definiciji pravno prepoznati od strane Komiteta isključivo kroz svoje organizacije. ${ }^{18}$ Dodaje se i da su nedržavni akteri kolektivni entiteti sastavljeni od pojedinaca, organizovani tako da imaju unutrašnju strukturu i pravila za ostvarivanje postavljenih ciljeva, te da funkcionišu jedan ograničen vremenski period..$^{19}$ Međutim, nezavisno od definicije nedržavnih aktera, njihovo prilagođavanje u međunarodni pravni sistem otežano je konvencionalnom, pozitivističkom doktrinom međunarodnog prava, koja je u osnovi određena akterima koje primarno reguliše: suverenim državama. ${ }^{20} \mathrm{~Pa}$ ipak, uprkos potcenjivanju u okviru državo-centričnog normativnog sistema, nedržavni akteri svakako bacaju novo svetlo na dinamiku stvaranja i primene međunarodnog prava. ${ }^{21}$ Činjenica je da su brojne državne funkcije dezintegrisane i delegirane nedržavnim entitetima kao što su transnacionalne mreže državnih službenika, javno-privatna administrativna tela koja operišu

${ }^{16}$ Christian N. Okeke, Controversial Subjects of Contemporary International Law - an examination of the new entitites of international law and their treaty-making capacity, op. cit., p. 207.

${ }^{17}$ Izveštaj Komiteta za nedržavne aktere Udruženja za međunarodno pravo, First report of the committee "Non-state actors in international law: aims, approach and scope of project and legal issues", ILA - International Law Association, The Hague Conference, 2010, p. 6.

${ }^{18}$ Math Noortmann, "The International Law Association and Non-State Actors: Professional network, public interest group or epistemic community?" in Participants in the International Legal System - Multiple Perspectives on non-state actors in International Law, (ed.) Jean d'Aspremont, Routledge Research in International Law, London, 2011, p. 255.

${ }^{19}$ Alessandro Chechi, "Non-state actors and cultural heritage: friends or foes?", Anuario de la Facultad de Derecho de la Universidad Autónoma de Madrid, 19 (2015), p. 459.

${ }^{20}$ Janne E. Nijman, "Non-state actors and the international rule of law: Revisiting the 'realist theory' of international legal personality", op. cit., p. 111.

${ }^{21}$ Jean d'Aspremont, "Non- state actors in International Law: Oscillating between Concepts and Dynamics", op. cit., p. 1. 
na međunarodnom nivou, ili nezavisna arbitražna tela sa specifičnim funkcionalnim nadležnostima. ${ }^{22}$ To potvrđuje i izveštaj američkog nacionalnog obaveštajnog saveta "Globalni trend 2025 - transformisani svet“, predviđajući sledeće: „Trend ka većoj difuziji vlasti i moći koji dolazi za par decenija će se verovatno ubrzati zbog pojavljivanja novih globalnih igrača (...) i proširene snage nedržavnih aktera i mreža... Do 2025. godine, države neće više biti jedini i najvažniji akteri na međunarodnoj sceni, i moraće da se prilagode novoj realnosti. Ipak, transformacija će biti nepotpuna i nejednaka. Iako države neće nestati sa međunarodne scene, relativna moć različitih nedržavnih aktera uključujući preduzeća, plemena, verske organizacije, čak i kriminalne mreže - će rasti, kako ove grupe u sve većem rasponu budu uticale na odlučivanje o društvenim, ekonomskim i političkim pitanjima."(...) (prevod V.P.) $)^{23}$

Danas, nedržavni akteri faktički obuhvataju raznovrsne entitete, počev od nevladinih organizacija, pojedinaca, ali i manjina - urođeničkih naroda, preko terorističkih grupa, pa sve do multinacionalnih kompanija. Raznovrsnost nije jedini atribut kojim se mogu pohvaliti, budući da ne postoji nijedna oblast međunarodnog prava u kojoj nedržavni akteri, $\mathrm{u}$ većoj ili manjoj meri, nisu uticali na stvaranje, razvoj ili bar način primene pravnih normi. Stoga, međunarodnopravni poredak sve više podseća na kaleidoskop sačinjen od mnoštva nedržavnih aktera, koji različitim aktivnostima utiču na dinamiku međunarodnih odnosa. Na taj način, pojavom posebnih pravnih režima, krhki pojam pravnog subjektiviteta postaje podložan fragmentaciji.

Zadati opseg ovog istraživanja ne dozvoljava nam da zaronimo dublje u potencijalni subjektivitet svih nedržavnih aktera, te ćemo našu analizu usmeriti na međunarodnopravni položaj investitora i pitanje

${ }^{22}$ Nehal Bhuta, "The Role International Actors Other Than States can Play in the New World Order", Realizing Utopia: The Future of International Law, (ed.) Antonio Cassese, Oxford University Press, USA, 2012, p. 66.

${ }^{23}$ Izveštaj američkog nacionalnog obaveštajnog saveta, "Global Trends 2025: A Transformed World", National Intelligence, Council USA, dostupno na https:/ / www.dni.gov/files/documents/Newsroom/Reports\%20and\%20Pubs/ 2025_Global_Trends_Final_Report.pdf, pristupljeno 1.3.2020, p. 81 . 
njihovog subjektiviteta. Strani investitori, najčešće oličeni kroz multinacionalne kompanije, atributom svoje privredne moći sve hrabrije preispituju tradicionalno etatističku koncepciju međunarodnih odnosa. Njihov istaknuti položaj ne počiva 'samo' na privrednoj snazi - pravni mehanizmi koje investitori uživaju izazivaju mnoštvo kontroverzi u međunarodnom pravu. Imajući u vidu sve veću složenost delovanja investitora na međunarodnom planu, cilj predmetnog istraživanja jeste da rasvetli određene pravne dileme, ukaže na različite doktrinarne stavove, te da analizira formalni ali i faktički uticaj investitora $u$ međunarodnom pravu, pružajući zaključak o njihovom eventualnom međunarodnopravnom subjektivitetu.

\section{MEĐUNARODNO INVESTICIONO PRAVO - POJAM, ZNAČAJ I IZVORI}

Pravo stranih investicija sastoji se od opšteg međunarodnog prava, specifičnih standarda međunarodnog privrednog prava, i posebnih pravila svojstvenih zaštiti stranih ulaganja. ${ }^{24} \mathrm{U}$ redovima koji slede, pored značaja stranih investicija i pojma stranog investitora, posvetićemo se određenim pravnim izvorima koji jesu, ili mogu biti, od značaja za dalji razvoj međunarodnog investicionog prava. Iako je ključna za održivost međunarodnog investicionog režima zaštite, doktrina izvora investicionog prava je - donekle paradoksalno - bila objekat nedovoljne pažnje i teorijskog promišljanja u literaturi. ${ }^{25}$ Imajući u vidu nivo razvoja međunarodnog investicionog prava, smatramo da naše istraživanje treba da obuhvati i doktrinu izvora.

${ }^{24}$ Rudolf Dolzer, Christoph Schreuer, Principles of International Investment Law, Oxford University Press, New York, 2008, p. 3.

${ }^{25}$ Jean d'Aspremont, "International Customary Investment Law: Story of a Paradox", in International Investment Law: The Sources of Rights and Obligations, (eds.) Tarcisio Gazzini, Eric Brabandere, Nijhoff International Investment Law (Book 1), The Netherlands, 2012, p. 8. 


\section{Značaj stranih investicija i pojam stranog investitora ${ }^{26}$}

Najznačajniji faktor savremene globalizovane ekonomije predstavljaju direktne strane investicije multinacionalnih kompanija. ${ }^{27}$ Naime, direktna strana ulaganja jedan su od temelja međunarodnog političkog i ekonomskog sistema. ${ }^{28}$ Nakon 1945 . godine i perioda obnove, tempo rasta stranih investicija polako se ubrzavao, podstaknut tehnološkim razvojem i smanjenim troškovima prevoza, ${ }^{29}$ te se osamdesete i početak devedesetih godina prošlog veka mogu nazvati prekretnicom $u$ razvoju međunarodnog investicionog prava. ${ }^{30}$ Sa početkom XXI veka prihvaćeno je da je jedna od funkcija direktnih stranih investicija ostvarivanje vladavine prava $\mathrm{u}$ zemljama $\mathrm{u}$ razvoju. ${ }^{31}$ Prema tome, međunarodni ulagački poduhvati pozitivno utiču na razvoj kako država uvoznica tako i država izvoznica kapitala, i svojim prednostima spajaju interese tri subjekta: samog ulagača, države čije državljanstvo ili nacionalnu

${ }^{26}$ Zbog čestog ekonomskog delovanja investitora kroz multinacionalne korporacije, a dosta ređe u ulozi pojedinca, prilikom rasprave o eventualnom međunarodnopravnom subjektivitetu stranih investitora, koristiće se naizmenično i termin multinacionalne korporacije. Budući da Zakon o stranim ulaganjima Republike Srbije prihvata termin "ulaganja“, dok se u literaturi prevashodno koristi termin "investicije“, u našem istraživanju koristićemo oba termina naizmenično. Zakon o stranim ulaganjima https://www.paragraf.rs/propisi/zakon_o_ulaganjima.html Službeni glasnik RS, br. 89/2015 i 95/2018.

${ }^{27}$ Peter Malanczuk, "Multinational Enterprises and Treaty-Making- A Contribution to the Discussion on Non-State Actors and the "Subjects" of International Law", in Multilateral Treaty-Making: The Current Status of Challenges to and Reforms Needed in the International Legislative Process, (ed.)Vera Gowlland-Debbas, Nijhoff Law Specials Vol. 47, Springer Netherlands, 2000, p. 49.

${ }^{28}$ W. Michael Reisman, "The Future of International Investment Law and Arbitration", in Realizing Utopia: The Future of International Law, (ed.) Antonio Cassese, Oxford University Press, USA, 2012, p. 276.

${ }^{29}$ Rudolf Dolzer, Christoph Schreuer, Principles of International Investment Law, op. cit., p. 1 .

${ }^{30}$ Jean d'Aspremont, "International Customary Investment Law: Story of a Paradox", op. cit., p. 15.

${ }^{31}$ W. Michael Reisman, "The Future of International Investment Law and Arbitration", op. cit., p. 278. 
pripadnost on ima, i države prijemnice ulaganja. ${ }^{32}$ Strane investicije, prema intenzitetu uticaja stranog investitora na upravljanje investicijom, mogu da se podele na direktne i indirektne. Kod direktnih investicija, ulagač ima intenzivne veze sa državom na čijoj teritoriji se ulaganje vrši, neposredno upravlja ulaganjem i aktivno ga kontroliše. Indirektne investicije podrazumevaju manja upravljačka prava i manji rizik za investitora koji samo posredno ulaže u državu domaćina kroz, primera radi, kupovinu hartija od vrednosti, akcija kompanije i slično. Težište našeg istraživanja usmeravamo na položaj investitora koji vrši direktno međunarodno ulaganje. Strani investitori su najčešće pojedinci (fizička lica) ili kompanije (pravna lica). ${ }^{33}$ U slučaju fizičkih lica, potvrda državljanstva izdaje se uglavnom od strane nadležnog organa države pojedinca. ${ }^{34}$ Kada je reč o korporacijama, utvrđivanje tzv. ",državljanstva“ znatno je složenije, i uglavnom se kao kriterijum koristi mesto osnivanja ili mesto glavnog sedišta (siège social). ${ }^{35} \mathrm{U}$ cilju što sveobuhvatnijeg sagledavanja položaja, ali i uticaja koji strani investitori uživaju u međunarodnom pravu, $\mathrm{u}$ narednim redovima analiziraćemo izvore na kojima počiva međunarodno investiciono pravo.

Izvori međunarodnog investicionog prava

\section{Međunarodni investicioni sporazumi}

Međunarodno investiciono pravo nastanak duguje ugovorima koji su zaključivani između stranog investitora i države domaćina (državom na čijoj teritoriji se investicija realizuje). Budući da opšta zakonska regulativa države domaćina često nije adekvatna da obuhvati specifičnosti investicionog projekta i prirodu uključenih interesa, investitor i država domaćin često pristupaju zaključenju investicionih

\footnotetext{
${ }^{32}$ Marko Z. Jovanović, Odgovornost države za zaštitu stranih direktnih ulaganja, doktorska disertacija, Pravni fakultet Univerziteta u Beogradu, neobjavljeno, str. 7.

${ }^{33}$ Rudolf Dolzer, Christoph Schreuer, Principles of International Investment Law, op. cit., p. 46.

${ }^{34}$ Ibid., p. 47.

${ }^{35}$ Ibid., p. 49.
} 
ugovora. ${ }^{36} \mathrm{U}$ tom smislu, razlikujemo bilateralne (Bilateral Investment Treaties, $\mathrm{u}$ daljem tekstu: BIT), regionalne i multilateralne investicione ugovore. Era zaključivanja investicionih sporazuma počela je 1959. godine, kada su Nemačka i Pakistan zaključile prvi BIT koji je stupio na snagu 1962. ${ }^{37}$ Dvostrani sporazumi o zaštiti i podsticanju stranih direktnih ulaganja predstavljaju međudržavne ugovore kojima se potpisnice međusobno obavezuju da ulagače koji imaju nacionalnu pripadnost druge države ugovornice na svojoj teritoriji tretiraju na sporazumom predviđeni način. ${ }^{38}$ BIT-ovi se uklapaju $u$ definiciju ugovora u okviru člana 2. (1) (a) Bečke konvencije o ugovornom pravu, ${ }^{39}$ budući da pripadaju međunarodnim ugovorima zaključenim između država u pismenoj formi i regulisani su međunarodnim pravom. ${ }^{40} \mathrm{Kada}$ je reč o regionalnim investicionim ugovorima, izdvojili bismo već poznati trgovinski ugovor zaključen između Sjedinjenih Američkih Država, Meksika i Kanade, NAFTA ${ }^{41}$ (North American Free Trade Agreement), kao i Ugovor o energetskoj povelji ECT (Energy Charter Treaty) ${ }^{42} \mathrm{Od}$ multilateralnih investicionih ugovora svakako je najpoznatija Vašingtonska konvencija o rešavanju investicionih sporova između države i državljana drugih država, na osnovu koje je 1965. godine ustanovljen Međunarodni centar za rešavanje investicionih sporova ICSID (International Centre for Settlement of Investment Disputes), od strane

${ }^{36}$ Ibid., 72.

${ }^{37}$ Ibid., op. cit., p. 18.

${ }^{38}$ Marko Z. Jovanović, Odgovornost države za zaštitu stranih direktnih ulaganja, op. cit., str. 93.

${ }^{39}$ Bečka konvencija o ugovornom pravu, dostupno na https:/ / treaties.un.org/doc/ Publication/UNTS/Volume\% 201155/volume-1155-I-18232-English.pdf, pristupljeno: 2.3.2020.

${ }^{40}$ Tarcisio Gazzini, "Bilateral Investment Treaties", in International Investment Law: The Sources of Rights and Obligations, Nijhoff International Investment Law (Book 1), The Netherlands, 2012, (eds.) Tarcisio Gazzini, Eric Brabandere, p. 106.

${ }^{41}$ North American Free Trade Agreement, NAFTA, dostupno na: https:/ / www.nafta-sec-alena.org/Home/Texts-of-the-Agreement/North-AmericanFree-Trade-Agreement, pristupljeno: 2.3.2020.

42 Energy charter treaty, dostupno na: https:/ / www.energycharter.org/ process/ energy-charter-treaty-1994/energy-charter-treaty/, pristupljeno 2.3.2020. 
Svetske banke. ${ }^{43}$ Dakle, $\mathrm{u}$ navedenim investicionim ugovorima, pregovarački proces vodi se između dve ili više suverenih država i rezultira ugovaranjem standarda koji će se primenjivati na investicije stranog investitora koje se preduzimaju na teritoriji druge države. Kakva je i kolika uloga investitora u navedenom pregovaračkom procesu koji se odigrava između država? Investitori mogu imati određenu ulogu u iniciranju, pregovaranju i uobličavanju pravnih tekstova koji kasnije bivaju usvojeni u vidu deklaracija, ugovora, ili čak obavezujućih konvencija. Iako njihova uloga $u$ čitavom pregovaračkom procesu nije očigledna, to ne sprečava privredne lobističke strukture da u njemu indirektno učestvuju.

Međutim, pored navedenih bilateralnih, regionalnih i multilateralnih ugovora, za naše istraživanje su posebno interesantni ugovori koje strani investitor direktno zaključuje sa državom domaćinom. Dakle, investitori direktno vode pregovore sa državom $u$ koju planiraju da investiraju, a rezultat takvih direktnih pregovora jesu tzv. „internacionalizovani“ ili "državni“" ugovori. Državni ugovori predstavljaju jedinstven izvor prava i obaveza $u$ međunarodnom investicionom pravu. ${ }^{44}$ Oni se najčešće zaključuju u vidu razvojnih sporazuma ili naftnih koncesija, dozvoljavajući stranom investitoru da eksploatiše prirodne resurse na teritoriji države domaćina. ${ }^{45}$ Da bi ugovor mogao poneti karakter državnog, neophodno je da ispuni dva uslova: prvo, druga ugovorna strana mora biti fizičko ili pravno lice (ugovori zaključeni između preduzeća u državnom vlasništvu i države, ili između dva preduzeća u državnom vlasništvu, ne smatraju se generalno državnim ugovorima). ${ }^{46}$ Drugo, fizičko ili pravno lice mora

${ }^{43}$ ICSID, International Centre for Settlement of Investment Disputes, dostupno na https:/ /icsid.worldbank.org/en/, pristupljeno 2.3.2020.

${ }^{44}$ Patrick Dumberry, "International Investment Contracts", in International Investment Law: The Sources of Rights and Obligations, Nijhoff International Investment Law (Book 1), The Netherlands, 2012, (eds.) Tarcisio Gazzini, Eric Brabandere, p. 215.

${ }^{45}$ Peter Malanczuk, "Multinational Enterprises and Treaty-Making - A Contribution to the Discussion on Non-State Actors and the "Subjects" of International Law", op. cit., p. 58.

${ }^{46}$ Patrick Dumberry, "International Investment Contracts”, op. cit., p. 217. 
poticati iz države koja nije država domaćin, kako bi ugovor stekao karakter međunarodnog. ${ }^{47}$ Sudeći po klauzuli o izboru merodavnog prava koje takvi ugovori predviđaju, oni uglavnom nisu regulisani određenim nacionalnim pravnim sistemom (npr. pravnim sistemom države domaćina), već upravo međunarodnim pravom. ${ }^{48}$ Naravno, svrha takve klauzule jeste pravna sigurnost, odnosno pokušaj da se izbegne situacija gde bi država domaćin zaobišla ispunjenje ugovornih obaveza delujući u lošoj veri, te zloupotrebivši sopstvene pravne norme. ${ }^{49}$ Budući da je investitor tzv. slabija ugovorna strana, ${ }^{50}$ te da je teritorijalno izložen državi domaćinu i njenim propisima, često takvi ugovoru sadrže dodatne klauzule kako bi ojačale njegov položaj. Mogu se uključiti i druge klauzule poput tzv. implementacione klauzule, koja stipuliše da će ugovor biti implementiran u pravnom sistemu države, ili tzv. stabilizacione klauzule, kako bi finansijski, ekonomski ili zakonski uslovi koji su postojali u vreme zaključenja, ostali neizmenjeni tokom perioda trajanja ugovora. ${ }^{51}$ Međutim, ono što je specifično i jedinstveno kod internacionalizovanih ugovora jeste činjenica da iako nisu formalni izvor međunarodnog prava (prema članu 38 Statuta Međunarodnog suda pravde), ipak predstavljaju „očigledan izvor prava $i$ obaveza za državu domaćina" (podvukla V.P.) u okviru međunarodnog investicionog prava. ${ }^{52} \mathrm{U}$ doktrini je razvijena veoma živa

${ }^{47}$ Ibid.

${ }^{48}$ Peter Malanczuk, "Multinational Enterprises and Treaty-Making: A Contribution to the Discussion on Non-State Actors and the "Subjects" of International Law", op. cit., p. 58.

${ }^{49} \mathrm{Ibid}$.

${ }^{50}$ Međutim, jedna od kritika pravnog okvira koji reguliše međunarodno investiciono pravo je da se veća zaštita pruža investitoru, nego državi. U tom kontekstu su pojedine zemlje počele da pregovaraju i stvaraju tzv. novu generaciju međunarodnih investicionih ugovora koji bi izjednačili zaštitu države i investitora. Vidi: Andrea Nikolić, „Inovativne klauzule afričkih bilateralnih investicionih ugovora“, Identitetski preobražaj Srbije, Prilozi projektu 2018 - kolektivna monografija, (ur.) Ivana Krstić, Maja Lukić Radović, Pravni fakultet Univerziteta u Beogradu, Beograd, 2019, str. 337-353.

${ }^{51}$ Peter Malanczuk,"Multinational Enterprises and Treaty-Making - A Contribution to the Discussion on Non-State Actors and the "Subjects" of International Law", op. cit., p. 58. 
diskusija povodom prirode „internacionalizovanih“ ugovora. Veoma različiti stavovi izneseni su povodom pitanja da li takvi ugovori predstavljaju ugovor u smislu međunarodnog javnog prava, ili se oni nalaze $u$ sferi međunarodnog privatnog prava. Na prvi pogled može delovati da rasprava oko njihove klasifikacije nosi samo terminološki značaj. No, smatramo da pitanje opravdano uživa veliki značaj, budući da se u slučaju prihvatanja međunarodne klasifikacije ugovora, otvara put ka potencijalnom shvatanju stranog investitora kao delimičnog subjekta međunarodnog prava.

Đorđević, na primer, smatra da sporazumi država sa pravnim licima unutrašnjeg prava, sa pojedincima, privatnim organizacijama, bankama, korporacijama i slično, nisu ugovori u smislu međunarodnog ugovornog prava. ${ }^{53}$ No, Okeke (Christian N. Okeke) ističe da ništa u teoriji međunarodnog prava ne sprečava ograničene subjekte međunarodnog prava da zaključuju pravno obavezujuće sporazume. ${ }^{54}$ Odnosno, entiteti kao što su Sveta stolica, pobunjenici, nevladine organizacije, ili čak međunarodne privatne korporacije (podvukla V.P.) mogu zaključivati međunarodno obavezujuće pravne akte. ${ }^{55}$

S druge strane, sudska praksa je dotakla ovo pitanje u slučaju Srpski zajmovi iz 1929. godine (Serbian loans) gde je istaknuto da „bilo koji ugovor koji nije ugovor zaključen između država kao subjekta međunarodnog prava, počiva na nacionalnom pravu određene države ${ }^{\prime \prime}$

\footnotetext{
52 Patrick Dumberry, “International Investment Contracts”, op. cit., p. 219.

53 ,Kada se pojavljuje država kao strana ugovornica sa drugim subjektima privatnog prava, mišljenja smo da se u našoj međunarodnopravnoj doktrini...nije dovoljno ulazilo u bliže raščlanjivanje suštine pravne prirode takvih ugovora...To su tzv. granični slučajevi koji zahtevaju interdisciplinarno istraživanje...U doktrini se pojavljuju pojmovi kao što su internacionalizacija ugovora, internacionalni ugovor, međunarodna osnova, međunarodna priroda ovakvih ugovora i dr.", Stevan Đorđević, Pravo međunarodnih ugovora, zbornik radova, Pravni fakultet Univerziteta u Beogradu, Beograd, 2011, str. 21-22.

${ }^{54}$ Christian N. Okeke, Controversial Subjects of Contemporary International Law - an examination of the new entitites of international law and their treaty-making capacity, op. cit., p. 220.

${ }^{55}$ Ibid.
} 
(prevod V.P.) ${ }^{56}$ Kada je reč o arbitražnoj praksa, ključno je pomenuti suprotan stav koji je zauzet u sada već čuvenoj arbitražnoj odluci The Texaco Company v. The Government of the Libyan Arab Republic. ${ }^{57} \mathrm{U}$ ovoj odluci arbitar-pojedinac, Rene Žan Dipui (René-Jean Dupuy) uzeo je u obzir ne samo nesumnjivi razvoj međunarodnog prava od vremena donošenja presude Srpski zajmovi, ali i rastuću 'delokalizaciju' ugovora pod pritiskom međunarodne trgovine. ${ }^{58}$ Uzdizanje ugovora na nivo međunarodnog zasnovao je na tri kriterijuma: prvo, klauzula o merodavnom pravu predviđala je opšta pravna načela (iako se ona ne mogu uvek u potpunosti smatrati međunarodnim pravom), zatim, klauzula koja je za sve moguće nedoumice $u$ tumačenju i izvršenju ugovora predviđala nadležnost arbitražnog tribunala, i konačno, činjenica da je bila reč o kategoriji razvojnih ekonomskih ugovora. ${ }^{59} \mathrm{Na}$ osnovu izloženih argumenata, arbitar Dipui locirao je ovaj ugovor o koncesiji u domen međunarodnog prava. ${ }^{60}$

Takođe, moguća je i situacija u kojoj ugovorne strane kao merodavno pravo izaberu nacionalno pravo države domaćina, no to ne znači da je primena međunarodnog prava potpuno isključena. ${ }^{61}$ Naprotiv, međunarodno pravo je deo domaćeg pravnog sistema $\mathrm{u}$ mnogim zemljama kroz opšta pravna načela, te na taj način

\footnotetext{
56 "Any contract which is not a contract between States in their capacity as subjects of international law is based on the municipal law of some country", Permanent Court of International Justice, Case concerning the payment of various Serbian loans issued in France, 1929, p. 41, dostupno na https:/ / www.icj-cij.org/files/permanentcourt-of-international-justice/serie_A/A_20/62_Emprunts_Serbes_Arret.pdf, pristupljeno 3.3.2020.

${ }^{57}$ The Texaco Overseas Petroleum Company and California Asiatic Oil Company v. The Government of the Libyan Arab Republic, dostupno na https://www.translex.org/261700/_/texaco-overseas-petroleum-company-v-the-government-ofthe-libyan-arab-republic-yca-1979-at-177-et-seq-/ pristupljeno 4.3.2020.

${ }^{58}$ Julien Cantegreil, "The Audacity of the Texaco/Calasiatic Award: René-Jean Dupuy and the Internationalization of Foreign Investment Law", The European Journal of International Law, Vol. 22 no. 2, 2011, p. 444.

${ }^{59}$ Ibid., p. 445.

${ }^{60}$ Ibid.

${ }^{61}$ Patrick Dumberry, “International Investment Contracts”, op. cit., p. 226.
} 
međunarodno pravo na zadnja vrata biva primenjeno kao merodavno pravo investicionog ugovora. ${ }^{62}$

Smatramo da su državni ugovori veoma značajni za analizu međunarodnopravnog položaja investitora. Ukoliko uporedimo položaj investitora pod BIT-ovima, gde je njihova uloga pasivna, zavisna od sopstvene države i bez značajnog manevarskog pregovaračkog prostora, sa položajem investitora pod državnim ugovorima, gde oni ravnopravno sa državom domaćinom učestvuju u pregovaranju i definisanju uslova budućeg ugovora, možemo zaključiti da su potonji ugovori svojevrsna ulaznica investitora u predvorje međunarodnopravnog subjektiviteta. Kombinacija materijalnih i proceduralnih prava, ${ }^{63}$ koja se nalaze $u$ ovim ugovorima, jeste indikacija da multinacionalne korporacije poseduju međunarodnu pravnu ličnost pod tim ugovorom (podvukao autor). ${ }^{64}$

\section{Međunarodno običajno pravo}

Zaključci Komisije za međunarodno pravo o identifikaciji običajnog prava govore nam da se akti nedržavnih aktera (pojedinaca, nevladinih organizacija, transnacionalnih korporacija itd.) ne doprinose nastanku običajnog prava, te da ne mogu služiti kao direktni (primarni) dokaz njegovog postojanja, ali ne poriču mogućnost njihove indirektne uloge u tom procesu. ${ }^{65}$ Međutim, to ne znači da ne postoji nikakva veza između nedržavnih aktera i stvaranja međunarodnog običajnog prava. Nedržavni akteri kao što su nevladine organizacije i korporacije, često utiču na razvoj običajnih pravila. ${ }^{66}$ Ganing (Isabelle Gunning) predlaže čak

62 „,Neki slučajevi, kao što je ICC Pyramid case, čak predlažu da u takvim situacijama međunarodno pravo treba da nadjača nacionalno pravo." Ibid.

${ }^{63}$ Pod proceduralnim pravima investitora koja izviru iz internacionalizovanih ugovora mislimo na mogućnost direktnog podnošenja tužbe arbitražnom tribunalu, što je detaljnije obrađeno u delu posvećenom analizi investicionih sporova.

${ }^{64}$ Patrick Dumberry, "International Investment Contracts," op. cit. p. 220.

${ }^{65}$ Draft conclusions on identification of customary international law, with commentaries, 2018, https://legal.un.org/ilc/texts/1_13.shtml, pristupljeno 5.3.2020.

${ }^{66}$, ,Kroz procese lobiranja i poziva na bojkot, oni poseduju indirektan uticaj koji u krajnjem stepenu može uticati na ponašanje i izjave države." Anthea Elizabeth 
da nedržavni akteri treba da imaju direktnu ulogu u stvaranju običajnog pravila. ${ }^{67}$ Naše istraživanje fokusiramo na strane investitore, čiji je odnos sa običajnim pravom predmet rastućeg doktrinarnog interesovanja.

Iako je postojanje ugovora dominantno u međunarodnom investicionom pravu, međunarodno običajno pravo i dalje igra važnu ulogu - ugovorna pravila moraju biti shvaćena i tumačena, kao i svi ugovori, u skladu sa opštim pravilima međunarodnog prava. ${ }^{68}$ Međutim, pitanje pravne zaštite investitora $u$ okviru međunarodnog običajnog prava oduvek je bilo kontroverzno. ${ }^{69}$ Upravo zbog nedostatka ustanovljenih običajnih pravila, države su se okrenule zaključivanju velikog broja BIT-ova. ${ }^{70}$ Njihov broj je sada izuzetno visok, ${ }^{71}$ i obim pitanja koje pokrivaju veoma širok, te je u doktrini aktuelna nova debata oko njihovog uticaja na postojanje običaja u međunarodnom investicionom pravu. ${ }^{72}$

Određen broj BIT-ova eksplicitno upućuje na međunarodno običajno pravo prilikom određivanja merodavnog prava, ${ }^{73}$ što navodi neke autore

Roberts, "Traditional and Modern Approaches to Customary International Law: A Reconciliation", The American Journal of International Law, Vol. 95, p. 775.

${ }^{67}$ Isabelle R. Gunning, "Modernizing Customary International Law: The Challenge of Human Rights", Virginia Journal of International Law Association, 1991, pp. 22734, navedeno prema Anthea Elizabeth Roberts, "Traditional and Modern Approaches to Customary International Law: A Reconciliation", op. cit., p. 775.

${ }^{68}$ Rudolf Dolzer, Christoph Schreuer, Principles of International Investment Law, op. cit., p. 17.

${ }^{69}$ Patrick Dumberry, "Are BITs Representing the "New" Customary International Law in International Investment Law?", Penn State International Law Review, Volume 28, Number 4, 2010, p. 676.

${ }^{70}$ Ibid., p. 701.

${ }^{71}$ Ukupno je zaključeno 2.897 , dok je na snazi 2.338 bilateralnih investicionih sporazuma. Statistika je dostupna na https://investmentpolicy.unctad.org/ international-investment-agreements, pristupljeno 5.5.2020.

72 Patrick Dumberry, "Are BITs Representing the "New" Customary International Law in International Investment Law?" op. cit., p. 676.

${ }^{73}$ Jean d'Aspremont, "International Customary Investment Law: Story of a Paradox", op. cit., p. 20. 
da sadržaj BIT-ova izjednačavaju sa običajnim pravilima. ${ }^{74} \mathrm{D}^{\prime}$ Aspremon ističe da je zapravo nezamislivo zaključiti veliki broj BIT-ova koji sadrže slične standarde zaštite investitora, a istovremeno odreći tim BIT-ovima status običajnog pravila u međunarodnom investicionom pravu. ${ }^{75} \mathrm{~S}$ druge strane, Damberi (Patrick Dumberry) smatra da BIT-ovi mogu igrati važnu ulogu u kristalizaciji običajnih pravila, ali negira BIT-ovima samu ulogu običajnog pravila. ${ }^{76} \mathrm{Na}$ primer, on ističe da samo konkretna obaveza države (na primer da se stranom investitoru obezbedi pravičan i jednak tretman) može biti podvrgnuta ispitivanju da li je reč o običajnom pravilu, smatrajući da je nemoguće da se izvrši analiza BIT-ova in toto. ${ }^{77}$

Dolcer i Šrojer (RudolfDolzer, Christoph Schreur) naglašavaju da uloga običajnog prava dolazi do izražaja upravo u međunarodnim minimalnim standardima koje država domaćin mora da obezbedi stranom investitoru, a koje se ogledaju, na primer, $u$ pravičnom $i$ jednakom tretmanu, punoj zaštiti, sigurnosti, i primeni Hul (Hull) pravila kojim se investitoru obezbeđuje brza, adekvatna i delotvorna kompenzacija, a u slučaju eksproprijacije njegove imovine. ${ }^{78}$ Dodatno, $u$ slučaju popunjavanja pravnih praznina ili nedorečenosti BIT-a, običajno pravo može igrati pomoćnu ulogu. ${ }^{79}$ Možemo zaključiti da su upravo kroz višedecenijsko zaključivanje BIT-ova određena običajna pravila dobila svoju formu, bar kakvu danas poznajemo. Ta forma bila je motivisana ne samo željom da se podstakne investiciona klima, već da se klasično običajno pravo prilagodi ekonomskim potrebama, pogotovo

${ }^{74}$ Patrick Dumberry, "Are BITs Representing the "New" Customary International Law in International Investment Law?", op. cit. p. 676.

${ }^{75}$ Jean d'Aspremont, "International Customary Investment Law: Story of a Paradox", op. cit., p. 20.

${ }^{76}$ Patrick Dumberry, "Are BITs Representing the "New" Customary International Law in International Investment Law?" op. cit., p. 676.

${ }^{77}$ Ibid., p. 683.

${ }^{78}$ Rudolf Dolzer, Christoph Schreuer, Principles of International Investment Law, op. cit., p.16.

${ }^{79}$ Patrick Dumberry, "Are BITs Representing the "New" Customary International Law in International Investment Law?" op. cit., p. 701. 
zemalja u razvoju, te da se u krajnjoj liniji stranim investitorima pruži veća zaštita. Takođe, kao običajno pravilo treba pomenuti i ustanovu diplomatske zaštite, koja će biti bliže obrađena u poglavlju posvećenom rešavanju investicionih sporova.

\section{Opšta pravna načela}

Kao što je pomenuto $u$ delu posvećenom ugovorima, merodavno pravo u tzv. državnim ugovorima jeste, uglavnom, međunarodno pravo. Najčešće su to opšta pravna načela inkorporirana $u$ same odredbe ugovora, ili eventualno nacionalna pravna načela države domaćina koji nisu u suprotnosti sa međunarodnim pravom. ${ }^{80}$ Opšta pravna načela igrala su značajnu ulogu tokom razvojnog perioda međunarodnog investicionog prava, ali se i savremeni arbitražni tribunali često pozivaju na njih u svojim odlukama. ${ }^{81}$

Opšta pravna načela mogu da pomognu u prevazilaženju sukoba između međunarodnog javnog prava i privatno-pravnih sporova, tako što učestvuju u preoblikovanju međunarodnog investicionog prava i investicione arbitraže.$^{82} \mathrm{U}$ tom smislu, Šil (Schill) istražuje transformativni potencijal opštih pravnih načela u međunarodnom pravu, smatrajući da arbitražni tribunali mogu, njihovom primenom, da poboljšaju ishod donošenja odluka, sopstveno rezonovanje činjenica, kao i da postignu balans između prava investitora, s jedne strane, ali i javnog interesa, sa druge. ${ }^{83}$ Kada je reč o investicionim sporovima, bilo na osnovu BIT-ova ili državnih ugovora, investicioni tribunali su često primenjivali opšta pravna načela, i to na različite načine: počev od popunjavanja pravnih

\footnotetext{
${ }^{80}$ Peter Malanczuk, "Multinational Enterprises and Treaty-Making: A Contribution to the Discussion on Non-State Actors and the "Subjects" of International Law", op. cit., p. 58.

${ }^{81}$ Stephan W. Schill, "General Principles of Law and InternationaL Investment Law", in International Investment Law: The Sources of Rights and Obligations, Nijhoff International Investment Law (Book 1), The Netherlands, 2012, (eds.) Tarcisio Gazzini, Eric Brabandere, pp. 141-142.

${ }^{82}$ Ibid., p. 136.

${ }^{83}$ Ibid., p. 137.
} 
praznina, do pomoćnog sredstva u vidu tumačenja ugovora, sve do utvrđivanja međusobnih prava i obaveza strana u sporu. ${ }^{84}$ Jovanović ističe da zapravo standardi tretmana stranih ulaganja u svojoj osnovi predstavljaju opšte pravne principe čiji se sadržaj, tj. obim garantovane zaštite, manje ili više razlikuje od države do države, od zakona do zakona, i od sporazuma do sporazuma.$^{85}$ Stoga, upravo ova relativna neujednačenost čini standarde tretmana stranih ulaganja "plodnim tlom" za dedukciju opštih pravnih principa. ${ }^{86}$ Primeri opštih principa na koje se arbitražni tribunali oslanjaju uključuju postupanje u dobroj veri, načelo nemo auditur propriam turpitudinem allegans, ${ }^{87}$ princip estoppel, ${ }^{88}$ onus probandi, pravo da se bude saslušan i slično. ${ }^{89}$

\section{Jednostrani pravni akti}

Uprkos činjenici da jednostrani pravni akti nisu formalno uvršteni u čl. 38 Statuta Međunarodnog suda pravde kao izvori međunarodnog prava, oni su faktički podobni da u međunarodnopravnom poretku proizvedu prava i obaveze. To potvrđuje i Komisija za međunarodno pravo koja je 2006. godine usvojila Vodeće principe za jednostrane akte država koje stvaraju određena prava i obaveze, u kojim izlaže uslove neophodne da jednostrana izjava volje države proizvede obavezujuće pravno dejstvo onome kome je upućena. ${ }^{90}$

\footnotetext{
${ }^{84}$ Ibid., p. 141.
}

85 ,Ovo naročito dolazi do izražaja kod onih standarda čiji sadržaj nije u dovoljnoj meri kodifikovan ili gde postoje značajnije razlike $\mathrm{u}$ definisanju u uporednom pravu, kao što je primera radi, pravičan i pošten tretman." Marko Z. Jovanović, Odgovornost države za zaštitu stranih direktnih ulaganja, op. cit., str. 113.

${ }^{86}$ Ibid.

${ }^{87}$ Pravno načelo koji nosi značenje onemogućavanja sticanja koristi na osnovu sopstvene protivpravne radnje.

${ }^{88}$ Pravno načelo koje suštinski označava zabranu poricanja/menjanja sopstvene izjave date u prethodnoj fazi postupka.

${ }^{89}$ Rudolf Dolzer, Christoph Schreuer, Principles of International Investment Law, op. cit., p. 12, sa upućivanjem na relevantnu arbitražnu praksu.

${ }^{90}$ Vodeći principi za jednostrane akte država koje stvaraju određena prava i obaveze "Guiding Principles applicable to unilateral declarations of States capable of 
Kada je reč o vezi između stranih investicija i jednostranih akata, $u$ svom originalnom članku profesor Mbengue (Mbengue) ispituje ulogu nacionalnih investicionih zakona kao potencijalnih izvora međunarodnog investicionog prava. ${ }^{91}$ On ističe da se do određenog stepena, nacionalni zakoni kojima se regulišu strane investicije mogu smatrati jednostranim pravnim aktima države koji proizvode međunarodna dejstva. ${ }^{92} \mathrm{~Pa}$ tako, investitori imaju očekivanja da će im država u koju investiraju, jednostrano (podvukao autor) obezbediti uobičajen nivo zaštite i pravne sigurnosti, kako bi podstakla investicionu klimu. ${ }^{93}$ Naravno, domaći zakoni kojima se uspostavlja pravni režim stranih investicija mogu se veoma razlikovati, ne samo na regionalnom nivou, ili na osnovu pripadnosti određenim međunarodnim trgovinskim organizacijama, već čak i na nivou dve susedne države. No, uprkos promenljivosti normativnog sadržaja, zajednički sadržalac investicionih zakona jeste njihova uloga svojevrsnog kalupa prema kojem se oblikuje opšti pravni režim zaštite stranih investitora. ${ }^{94}$

Naravno, da bi jednostran akt bio međunarodno pravno relevantan, neophodno je da ispunjava opšte uslove za punovažnost, odnosno, potrebno je da je donet od strane nadležnog organa, da izražava stvarnu volju države, kao i da ima pravno dopušten predmet. ${ }^{95}$ No, pored navedenih uslova, osnov obaveznosti jednostranih akata jeste u nameri države da bude pravno obavezana, što dolazi do izražaja u slučaju stranih investitora. Tirlvej (Thirlway) na primer smatra da se jednostrani pravni akti mogu definisati kao ugovori $u$ nastajanju, koji su

creating legal obligations, with commentaries thereto", 2006, dostupno na https://legal.un.org/docs/?symbol=A/CN.4/L.703, pristupljeno: 10.4.2020.

${ }^{91}$ Makane Moïse Mbengue, "National Legislation and Unilateral Acts of States", in International Investment Law: The Sources of Rights and Obligations, Nijhoff International Investment Law (Book 1), The Netherlands, 2012, (eds.) Tarcisio Gazzini, Eric Brabandere, p. 183.

92 Ibid.

${ }^{93}$ Ibid., p.184.

${ }^{94}$ Ibid., p.186.

${ }^{95}$ Milenko Kreća, Međunarodno javno pravo, Pravni fakultet Univerziteta u Beogradu, 2017, str. 106. 
kompletirani naknadnim radnjama. ${ }^{96} \mathrm{U}$ tom smislu, može se reći da država domaćin, u želji da podstakne priliv stranih investicija, sebe jednostrano obavezuje kroz nacionalne zakone na određeno postupanje prema investitoru, što je otelotvoreno u standardima koji se investitoru garantuju. Na taj način, država se na međunarodnom planu jednostrano obavezuje investitoru, koji opet, sa svoje strane, gaji legitimna očekivanja da će navedeni standardi biti ispunjeni. Ta očekivanja se otelotvoruju kroz naknadni proces zaključenja investicionog ugovora.

\section{Zaključak}

Međunarodno investiciono pravo, nastalo na opštem međunarodnom pravu i obogaćeno specifičnim principima trgovinskog prava (lex mercatoria), kroz dinamične i transnacionalne investicione aktivnosti, može uticati u određenoj meri na preciziranje sadržine opštih pravnih pravila. Na primer, preplitanje investicionih principa i običajnih pravila najviše je izraženo u polju eksproprijacije imovine investitora, isplate kompenzacije, i uopšte uzev, zadiranjem u svojinska prava stranog investitora na teritoriji države domaćina. Dodatno, opšta pravna načela, rasuta i inkorporirana u brojne nacionalne pravne sisteme, mogu imati posebno važnu ulogu upravo $u$ navedenom tumačenju međunarodnih investicionih ugovora, budući da od njih može zavisiti stepen prava i zaštite koje uživa strani investitor na osnovu datog ugovora. U tom duhu, smatramo da arbitražni tribunali, ali i arbitripojedinci, imaju najširi manevarski prostor da tumače klasična pravna pravila $u$ novom svetlu, prilagođavajući ih potrebama trenutka i privrednog prava. Na taj način praksom sudova i tribunala može se posredno uticati na odlučivanja i ponašanje država. Na primer, države mogu strateški usklađivati sopstvene zakone kojima se reguliše priliv stranih investicija sa sudskom i arbitražnom praksom, čime se u krajnjoj liniji može ublažiti asimetrija između javnog i privatnog interesa.

${ }^{96}$ High Thirlway, The Sources of International Law, Oxford University Press, 2014, p. 21. 


\section{MEĐUNARODNI INVESTICIONI SPOROVI}

U ovom poglavlju našeg istraživanja, posvetićemo se izuzetno značajnom aspektu položaja investitora u međunarodnom pravu. Reč je o pravnim mehanizmima koji su investitoru na raspolaganju prilikom vođenja direktnih sporova sa državom na čijoj teritoriji realizuje svoju investiciju. Zajedno sa već pominjanim ovlašćenjima direktnog pregovaranja i zaključivanja internacionalizovanih ugovora, mehanizmi koji su ulagačima dostupni u investicionim sporovima predstavljaju ključ ka njihovom što preciznijem pozicioniranju u međunarodnopravnom poretku.

\section{Preteča savremenih investicionih sporova}

U okviru tradicionalnog međunarodnog prava, investitori nisu imali direktan pristup pravnim mehanizmima na osnovu kojih bi mogli, $\mathrm{u}$ slučaju kršenja njihovih prava, da tuže stranu državu. ${ }^{97}$ Stoga, pre proliferacije investicionih sporazuma, najčešće korišćen mehanizam za zaštitu stranih državljana i njihove imovine bio je institut diplomatske zaštite. ${ }^{98}$ Diplomatska zaštita je institut međunarodnog prava koji je proistekao iz veze države i njenog državljanina koja se može protegnuti i preko državnih granica. ${ }^{99} \mathrm{U}$ tom smislu, razvojem međunarodnog prava došlo se do toga da država ima pravo, uz zadovoljenje potrebnih uslova, da usled povrede prava njenom državljaninu, pokrene mehanizam diplomatske zaštite prema drugoj državi. ${ }^{100}$

${ }^{97}$ Rudolf Dolzer, Christoph Schreuer, Principles of International Investment Law, op.cit., p. 211.

${ }^{98}$ Javier García Olmedo, "Redefining the Position of the Investor in the International Legal Order and the Nature of Investment Treaty Rights: A Closer Look at the Relationship between Diplomatic Protection and Investor-State Arbitration", in Non-State Actors and International Obligations: Creation, Evolution and Enforcement, James Summers, Alex Gough (Eds.) Koninklijke Brill NV, Leiden, The Netherlands, 2018, p. 161.

${ }^{99}$ Bojan Milisavljević, ,"Razvoj instituta diplomatske zaštite u međunarodnom pravu“, Međunarodna politika, Institut za međunarodnu politiku i privredu, 2011, str. 80.

${ }^{100}$ Kao dva osnovna uslova, profesor Milisavljević navodi postojanje povrede prava državljana odnosne države i iscrpljenje unutrašnjih pravnih sredstava države 
Kalvo (Calvo) doktrina, kao izraz pravnog nacionalizma, blisko je povezana sa oblikovanjem instituta diplomatske zaštite. Nastala na tlu Latinske Amerike, kao svojevrstan odgovor ekonomskom imperijalizmu razvijenih država, ona je putem ugovorne klauzule predviđala odricanje od mogućnosti korišćenja diplomatske zaštite, kao i nepostojanje posebne zaštite prava stranaca i njihove imovine. Stranim državljanima nije samo bilo onemogućeno pravo diplomatske zaštite, već i pristup međunarodnim tribunalima, budući da je doktrina zastupala stav da strani državljani mogu isticati zahteve za zaštitu svojih prava isključivo pred sudovima države domaćina. ${ }^{101}$ Naravno, usložnjavanjem međunarodnih odnosa, Kalvo doktrina nije bila pogodna mera za privlačenje stranih investicija, te $u$ najvećoj meri danas napuštena. Verovatno njen najznačajniji doprinos leži u činjenici da je doprinela konstituisanju uslova za primenu diplomatske zaštite koji se sastoji od nužnosti iskorišćenja unutrašnjih sredstava zaštite prava stranih državljana. ${ }^{102}$

Tradicionalna koncepcija diplomatske zaštite vremenom je evoluirala $\mathrm{u}$ poseban skup pravila pod nazivom Minimalna prava stranaca (podvukao autor) koji je ukazivao na obavezu države da poštuje osnovna prava stranaca, pa čak i da ih u mnogim oblastima ne tretira lošije od sopstvenih državljana. ${ }^{103}$ Upravo na osnovu minimalnih prava stranaca, vremenom će se razviti, na temelju običajnog pravila, materijalnopravni standard zaštite stranih direktnih ulaganja. Danas, ranije pominjana ICSID konvencija formalno ostavlja mogućnost diplomatske zaštite u korist investitora, ali samo u slučaju da se država domaćin ne povinuje donetoj odluci arbitražnog tribunala. ${ }^{104}$ Dakle, tek ukoliko bi država

štetnika. Milenko Kreća, Bojan Milisavljević, Međunarodno pravo predstavljanja (diplomatsko i konzularno pravo), 2017, Pravni fakultet Univerziteta u Beogradu, str. 229.

${ }^{101}$ Rudolf Dolzer, Christoph Schreuer, Principles of International Investment Law, op. cit., p. 12.

${ }^{102}$ Milenko Kreća, Bojan Milisavljević, Međunarodno pravo predstavljanja (diplomatsko i konzularno pravo), op. cit., str. 246.

${ }^{103}$ Ibid., str. 257.

${ }^{104}$ Rudolf Dolzer, Christoph Schreuer, Principles of International Investment Law, op. cit., p. 213. 
prijemnica ulaganja povredila obavezu zaštite stranog direktnog ulaganja i uskratila stranom ulagaču pravo na delotvornu prinudnu zaštitu njegovih prava, spor između ulagača i države ulaganja bi se transformisao u spor između države prijemnice i države porekla ulagača. ${ }^{105} \mathrm{No}$, u praksi se takva opcija retko koristi. ${ }^{106}$

\section{Sporovi između države i stranog ulagača}

Kada se dinamika ugovornog investicionog odnosa naruši, a pregovori ne donesu pomak, između stranog investitora i države domaćina dolazi do investicionog spora. U tom slučaju, iz očiglednih razloga, investitor će želeti da izbegne rešavanje spora putem obraćanja domaćim sudovima države domaćina. Naime, postoji opravdana bojazan da nacionalni sudovi neće moći da dostignu odgovarajući stepen nezavisnosti i nepristrasnosti u sporu protiv sopstvene države. Šrojer dodaje kako ova opasnost postaje još izraženija kada je vrednost spora visoka, ${ }^{107}$ što je uglavnom i slučaj kod ulagačkih projekata. Takođe, ukoliko bi investitor pokušao da podnese tužbu sudovima neke treće države, a protiv države domaćina, suočio bi se sa neuspehom budući da bi takva tužba najverovatnije bila nedopuštena, a imajući u vidu pravila o imunitetu države. ${ }^{108}$

Nakon drugog svetskog rata, rast međunarodnih investicija se ubrzao, međutim, istovremeno je manjak pouzdanog i predvidljivog mehanizma za rešavanje sporova postao sve vidljiviji. ${ }^{109}$ Alternativa $u$

${ }^{105}$ Marko Z. Jovanović, Odgovornost države za zaštitu stranih direktnih ulaganja, op. cit., str. 56.

106 Ibid.

${ }^{107}$ Rudolf Dolzer, Christoph Schreuer, Principles of International Investment Law, op.cit., p. 214.

108 „ک̌ak i u državama koje primenjuju doktrinu restriktivnog imuniteta, tužbe protiv stranih država koje izviru iz investicionih sporova bi verovatno bile nedopuštene. Država domaćin u odnosu sa investitorom često nastupa kroz vršenje suverene vlasti (iure imperii), pre nego što nastupa u komercijalnom kapacitetu (iure gestionis)." Rudolf Dolzer, Christoph Schreuer, Principles of International Investment Law, op.cit., p. 215.

${ }^{109}$ Patrick Dumberry, Érik Labelle-Eastaugh, "Non-state actors in international investment law: To be or not to be? The legal personality of non-state actors in 
vidu zahteva za diplomatskom zaštitom, smatrana je dugotrajnim, komplikovanim i krajnje nepredvidivim načinom da se ostvari naknada zbog navodnog nepovoljnog tretmana od strane države domaćina. Dakle, nedostaci tradicionalnih metoda rešavanja sporova - diplomatske zaštite i tužbe pred domaćim sudovima, doveli su do ideje da se investitoru odobri direktan pristup efikasnijim međunarodnim procedurama, posebno arbitraži. ${ }^{110}$ To je opremilo strane investitore sa značajnim proceduralnim pravima $u$ odnosu na tradicionalne mehanizme diplomatske zaštite, dozvoljavajući im da direktno podnesu tužbu protiv države domaćina pred međunarodnim tribunalom koji će doneti konačnu i obavezujuću odluku. Investiciona arbitraža često je okarakterisana kao vrsta međunarodnog upravnog prava gde se tužena država direktno poziva na odgovornost zbog tretiranja stranog ulagača na način koji krši njene ugovorne obaveze. ${ }^{111}$ Ova karakteristika je opisana kao ,jedan od najvažnijih progresivnih razvoja u proceduri međunarodnog prava 20. veka." ${ }^{112}$

Ono što međunarodno investiciono pravo i njegov razvoj čini jedinstvenim, jeste da većina BIT-ova dozvoljava da sam investitor, delujući bez intervencije, dozvole ili blagoslova sopstvene države, aktivira međunarodni tribunal u cilju preispitivanja postupaka države domaćina. ${ }^{113}$

international investment law", in Participants in the International Legal System Multiple Perspectives on non-state actors in International Law, (ed.) Jean d'Aspremont, Routledge Research in International Law, London, 2011, p. 361.

${ }^{110}$ Rudolf Dolzer, Christoph Schreuer, Principles of International Investment Law, op.cit., p. 220.

111 Pierre Lalive, Laura Halonen, "On the availability of counterclaims in Investment Treaty Arbitration", in Rights of the Host State within the System of International Investment Protection, Czech Yearbook of International Law, Alexander J. Belohlavek, N. Rozehnalova (Eds.), 2011, Czech yearbook of International Law, p. 142.

${ }^{112}$ S.M. Schwebel, "The United States 2004 Model Bilateral Investment Treaty: An Exercise in the Regressive Development of International Law", Transnational Dispute Management, 2006, p. 2, navedeno prema Patrick Dumberry, Érik Labelle-Eastaugh, "Non-state actors in international investment law: To be or not to be? The legal personality of non-state actors in international investment law", op. cit., p. 361.

${ }^{113}$ W. Michael Reisman,"The Future of International Investment Law and Arbitration", op. cit., p. 279. 
Na osnovu BIT-a, ulagač se po pravilu ovlašćuje da spor protiv države prijemnice ulaganja direktno iznese pred neku međunarodnu arbitražu, bilo institucionalnu (Međunarodni centar za rešavanje ulagačkih sporova, arbitražu Međunarodne trgovinske komore u Parizu, Londonski međunarodni arbitražni sud) bilo ad hoc, čak i ukoliko nije bio u direktnom ugovornom odnosu sa tuženom državom i bez potrebe da prethodno zaključi poseban kompromis sa njom, jer se smatra da je država prijemnica ulaganja zaključenjem dvostranog sporazuma o zaštiti i podsticanju stranih direktnih ulaganja unapred dala ponudu svim ulagačima na njenoj teritoriji koji imaju državljanstvo ili nacionalnu pripadnost države saugovornice da bude tužena pred sporazumom ugovorenim forumom i odrekla se jurisdikcionog imuniteta. ${ }^{114}$

S druge strane, postoje autori koje ne smatraju da investitori poseduju specifična ovlašćenja $u$ postupku rešavanja investicionih sporova, odnosno da se ona ne mogu odvojiti od njihove matične države. Pa tako Olmedo (Olmedo) naglašava da između dva različita proceduralna mehanizma za rešavanje investicionih sporova: instituta diplomatske zaštite i samostalnih investicionih režima (bilateralnog ili multilateralnog investicionog ugovora), postoji zajednički pravni osnov koji se ogleda u činjenici državljanstva. ${ }^{115}$ Sledi da investitori nisu prepoznati kao subjekti prava nezavisno od države njihovog državljanstva, bilo da su pravna ili fizička lica, što indicira da imaju sličan status i na međunarodnom planu, odnosno nisu istinski subjekti međunarodnog prava. ${ }^{116}$ Izloženi argument bi se donekle mogao prihvatiti u slučaju bilateralnih i multilateralnih investicionih ugovora, koje međusobno zaključuju države, kao jedine ugovornice, čime garantuju zaštitu investitorima koji su državljani druge države. No, u slučaju internacionalizovanih (državnih) ugovora, gde investitori direktno vode pregovore sa državom

\footnotetext{
${ }^{114}$ Marko Z. Jovanović, Odgovornost države za zaštitu stranih direktnih ulaganja, op. cit., str. 6.

${ }^{115}$ Javier García Olmedo, "Redefining the Position of the Investor in the International Legal Order and the Nature of Investment Treaty Rights: A Closer Look at the Relationship between Diplomatic Protection and Investor-State Arbitration", op. cit., p. 159.

${ }^{116}$ Ibid.
} 
na čijoj teritoriji žele da ulažu, i nezavisno od svog državljanstva kreiraju jedan ugovorni odnos na međunarodnom planu, navedeni argument se ne bi mogao prihvatiti.

Naravno, puka činjenica da su ugovorne strane izabrale da njihov sporazum bude regulisan međunarodnim pravom ne čini automatski privatne entitete subjektima međunarodnog prava. ${ }^{117}$ Međutim, ovlašćenja koja strani investitor uživa jesu međunarodnopravne prirode. Najpre, kod internacionalizovanih ugovora, videli smo da je on ovlašćen da direktno pregovara sa državom oko uslova ulagačkog poduhvata i sadržine takvog ugovora. Zatim, investitor je u mogućnosti da direktno pokrene spor protiv države domaćina ukoliko smatra da mu nije pružen garantovani tretman, ili da je došlo do kršenja njegovih prava. I konačno, u slučaju da arbitražni tribunal odluči u njegovu korist, konstituiše se međunarodna odgovornost države i obaveza isplate naknade ulagaču.

U literaturi je istaknuta jedna struja mišljenja koja odriče stranim ulagačima mogućnost da ponesu svojstvo subjekta međunarodnog prava, ali to čini praveći paralelu sa položajem pojedinca u međunarodnom pravu. ${ }^{118}$ Ističe se kako je pojedinac takođe ovlašćen da tuži državu ukoliko smatra da mu je prekršeno neko pravo u okviru regionalnog sistema zaštite oličenog kroz Evropski sud za ljudska prava, ali da u krajnjoj liniji ni pojedinac nije subjekt međunarodnog prava. Smatramo da identična paralela između položaja investitora sa položajem pojedinca u međunarodnom pravu nije moguća. Najpre, istina je da pojedinac može pokrenuti postupak kojim bi se preispitalo delovanje države, a u okviru zaštite zajemčenih ljudskih prava. Ipak, pojedinac nije ovlašćen da direktno pregovara sa državom oko konačne sadržine ugovora kojim se predviđa zaštita. Takođe, investicioni ugovori mogu da štite prava stranog investitora u toliko širokom opsegu, da mogu ozbiljno ograničiti

${ }^{117}$ Christian N. Okeke, Controversial Subjects of Contemporary International Law - an examination of the new entitites of international law and their treaty-making capacity, op. cit., p. 214.

${ }^{118}$ Videti na primer, Peter Malanczuk, "Multinational Enterprises and TreatyMaking - A Contribution to the Discussion on Non-State Actors and the "Subjects" of International Law". 
državu domaćina u donošenju pravnog okvira zaštite ljudskih prava, a u slučaju da mere predviđene takvim okvirom nepovoljno utiču na vrednost investicije. ${ }^{119}$ Konačno, u slučaju kršenja ljudskih prava, naknada štete $\mathrm{u}$ vidu kompenzacije nije uvek garantovana pojedincu, budući da Sud može samo konstatovati da je došlo do povrede i naložiti državi da povuče sporno zakonodavstvo. ${ }^{120} \mathrm{U}$ arbitraži između države i investitora, pretpostavljena naknada štete jeste puna kompenzacija za investitora, što je $\mathrm{u}$ potpunosti $\mathrm{u}$ skladu sa već dobro poznatim standardom odgovornosti za počinjenu štetu, koji je uspostavljen još u presudi Fabrika u Horžovu (Factory at Chorzow), a ne prosta odluka koja samo ohrabruje državu da povuče neodgovarajuće zakonodavne mere. ${ }^{121}$

\section{Zaključak}

U investicionoj arbitraži, države su uglavnom pasivni učesnici u igri kontrolisanoj od strane korporacija koje su najčešće u ulozi tužioca, gde potonje igraju pravnostvarajuću ulogu, koja je u najvećem delu međunarodnog prava rezervisana za države. ${ }^{122}$ One su (skoro uvek) inicijatori arbitražnog postupka za rešavanje sporova, i kao ključni akteri u istom, značajno utiču na tumačenje ugovornih odredbi od strane tribunala. ${ }^{123}$ Strani ulagači postaju svojevrstan "poverilac prvog reda“

${ }^{119}$ Yulia Levashova, "The Accountability and Corporate Social Responsibility of Multinational Corporations for Transgressions in Host States through International Investment Law", Utrecht Law Review, Volume 14, Issue 2, 2018, p. 43.

${ }^{120}$ Slikovit primer je presuda u slučaju Kafkaris v. Cyprus, u kojoj je Evropski sud za ljudska prava jednoglasno našao da samo konstatovanje činjenice kršenja prava predstavlja dovoljnu satisfakciju za nematerijalnu štetu koju je pretrpeo tužilac, gospodin Kafkaris. European Court of Human Rights, Grand Chamber Judgment Kafkaris v. Cyprus, https://hudoc.echr.coe.int/eng-press\#\{“itemid”:[“0032266462-2424484"]\}, pristupljeno 20.4.2020.

${ }^{121}$ José E. Alvarez, "Are Corporations “Subjects” of International Law?”, Santa Clara Journal of International Law, 1 (2011), p. 11.

122 Ibid.

${ }^{123}$ Patrick Dumberry, Érik Labelle-Eastaugh, "Non-state actors in international investment law: To be or not to be? The legal personality of non-state actors in international investment law", op. cit., p. 362. 
obaveze zaštite i kao "glavni kontrolor" ispunjenosti te obaveze, jer aktiviranje mehanizama pravne zaštite $u$ prvom redu zavisi direktno od njihove volje, a ne od volje države čiju pripadnost imaju, jer je jedna od opšteprihvaćenih ulagačkih privilegija mogućnost samostalnog pokretanja postupka pred većinom foruma za rešavanje ulagačkih sporova. ${ }^{124}$ Kao potpuni i jednaki partneri u ovim postupcima sa državom, korporacije igraju direktnu (podvukao autor) ulogu u oblikovanju sadržaja i evolucije međunarodnog investicionog prava, što je fenomen retko prisutan $u$ ostalim sferama međunarodnog prava. ${ }^{125}$ Damberi ističe da se entitet kvalifikuje kao subjekat međunarodnog prava u onom obimu u kojem može biti nosilac prava, i ukoliko mu je data mogućnost da podnese direktnu tužbu protiv države pred međunarodnim tribunalom, te da su ta dva uslova očigledno ispunjena $u$ kontekstu modernih investicionih ugovora. ${ }^{126}$ Strani ulagači, iako su subjekti privatnog prava postaju odlučujući faktor u pravnom uobličavanju i implementaciji pravila o odgovornosti države za zaštitu stranih direktnih ulaganja. ${ }^{127}$ Čini se da se tokom investicionog spora početna asimetrija $u$ odnosu između stranaka umanjuje, pružajući investitoru mogućnost da pokrene spor direktno protiv države u kojoj je izvršio ulaganje. Prema tome, posedovanje locus standi u investicionim sporova, kao i ovlašćenja direktnog pregovaranja i zaključivanja investicionih ugovora, jesu ključni elementi međunarodnog položaja investitora. Na taj način, popločava se put ograničenom subjektivitetu stranog investitora $\mathrm{u}$ međunarodnom pravu, što ćemo analizirati u redovima koji slede.

${ }^{124}$ Marko Z. Jovanović, Odgovornost države za zaštitu stranih direktnih ulaganja, op. cit., str. 56.

${ }^{125}$ Patrick Dumberry, Érik Labelle-Eastaugh, "Non-state actors in international investment law: To be or not to be? The legal personality of non-state actors in international investment law", op. cit., p. 360.

${ }^{126}$ Ibid.

${ }^{127}$ Marko Z. Jovanović, Odgovornost države za zaštitu stranih direktnih ulaganja, op. cit., str. 55-56. 


\section{OVLAŠĆENJA INVESTITORA U MEĐUNARODNOM PRAVU - ZAČETAK OGRANIČENOG SUBJEKTIVITETA?}

Ključno pitanje koje se nameće kao ishodišna tačka našeg istraživanja jeste kako se uticaj stranih investitora može obuhvatiti sa pravne tačke gledišta, te da li se oni mogu okarakterisati kao ograničeni subjekti međunarodnog prava?

Strani investitori poseduju sposobnost da budu nosioci prava i obaveza u međunarodnom pravu, no, često se navodi kako investitori ne poseduju direktnu pravnostvarajuću sposobnost, potrebnu da se definicija međunarodnopravnog subjektiviteta zaokruži. Smatramo da prilikom davanja negativnog suda o njihovoj pravnostvarajućoj sposobnosti ne treba biti isključiv. Uprkos nedostatku generalne pravnostvarajuće sposobnosti, treba istaći da je situacija donekle drugačije kod državnih ugovora. U državnim, odnosno internacionalizovanim ugovorima, investitor nije samo običan posmatrač, već je direktan učesnik u stvaranju pravnih normi (podvukao autor) i poseduje zakonodavnu moć na međunarodnom planu, sličnu moći države koja donosi ugovor. ${ }^{128}$ Takođe, Šo (Shaw) ističejedan mogući metod sticanja međunarodnopravne ličnosti, a to je podvrgavanje ugovora, zaključenog između subjekta međunarodnog prava i privatnog subjekta, direktno pravilima međunarodnog prava, čime potonji subjekt stiče međunarodnopravnu ličnost, a u kontekstu predmetnog ugovora. ${ }^{129}$ Dakle, multinacionalne kompanije u ulozi stranih investitora stiču međunarodnopravnu ličnost $\mathrm{u}$ ograničenom smislu, izvedenu iz investicionog ugovora i odobrenu od strane države kao međunarodni javni ugovor. ${ }^{130}$

Pitanje subjektiviteta $u$ međunarodnom pravu nerazdvojno je od kompleksnog pitanja odgovornosti. Kada je reč o stranim investitorima,

${ }^{128}$ Patrick Dumberry, Érik Labelle-Eastaugh, “Non-state actors in international investment law: To be or not to be? The legal personality of non-state actors in international investment law", op. cit. p.365.

${ }^{129}$ Malcolm N. Shaw, International Law, op. cit., p. 262.

${ }^{130}$ Peter Malanczuk, "Multinational Enterprises and Treaty-Making: A Contribution to the Discussion on Non-State Actors and the "Subjects" of International Law", op. cit., p. 72. 
čini se da njihov rastući uticaj nije proporcionalan sa njihovom odgovornošću. Očigledna prepreka u tom pogledu jeste upravo njihov položaj nedržavnih aktera, koji ne dozvoljava precizno uobličavanje međunarodne odgovornosti za načinjenu štetu. U tom smislu, primetno je da je predmet doktrinarnog istraživanja uglavnom šteta koju država domaćin može naneti investitoru, kao i načini na koji se investitor može zaštititi od iste, a ređe šteta koju sâm investitor može naneti državi domaćinu. U duhu rasprave o odgovornosti, važno je pomenuti i odluku ICSID arbitražnog tribunala u predmetu Urbaser v Argentina. Ova odluka, koja je primarno postala zapažena zbog protivtužbe države domaćina za kršenje ljudskih prava za koju se tribunal proglasio nadležnim, takođe je važna za naše istraživanje zbog sledećih zaključaka: (...)...,princip koji se može istaći u ovom slučaju, a prema kojem korporacije po svojoj prirodi ne mogu biti subjekti međunarodnog prava, i stoga, nisu sposobne da budu nosioci obaveza...Dok je ovaj princip imao svoju važnost u prošlosti, izgubio je svoj uticaj i značaj, u sličnim uslovima kao kada je reč o pojedincima. U svetlu trenutnog razvoja, ne može više biti prihvaćeno da su kompanije koje deluju na međunarodnom planu imune od međunarodnopravnog subjektiviteta" ...(... $)^{131}$ (prevod V.P.). Naravno, odluka nije prejudicirala da korporacije formalno jesu subjekti međunarodnog prava, ali je jasno pokazala da one mogu biti nosioci prava i obaveza u međunarodnopravnom poretku. Na toj liniji rezonovanja, ističe se da je samo posedovanje međunarodnih prava i obaveza dovoljno da bi se određeni entitet smatrao subjektom međunarodnog prava. ${ }^{132}$

Mogućnošću da strani investitori ponesu atribut ograničenih subjekata međunarodnog prava, otvara se mogućnost za konstituisanje krivične odgovornosti korporacija. Na taj način, konstituisala bi se šira

${ }^{131}$ Urbaser S.A. and Consorcio de Aguas Bilbao Bizkaia, Bilbao Biskaia Ur Partzuergoa v. The Argentine Republic, ICSID Case No. ARB/07/26, 2016, par. 1194-1195, p. 316317, dostupno na https://www.italaw.com/sites/default/files/case-documents /italaw8136_1.pdf, pristupljeno 15.5.2020.

${ }^{132}$ Davor Muhvić, "Legal Personality as a Theoretical Approach to Non-State Entities in International Law: The Example of Transnational Corporations", op. cit., p. 9. 
mreža odgovornosti za kršenje ljudskih prava, ali i zaštitu životne sredine, što bi u krajnjoj liniji doprinelo većoj pravnoj sigurnosti. Time bi se investitor podstakao da dugoročno dela opreznije prilikom upravljanja investicijom, što bi istovremeno moglo doprineti manjem broju arbitražnih sporova u budućnosti. ${ }^{133}$ Povećanjem njihove pravne vidljivosti kroz preciziranje odgovornosti smanjila bi se očigledna neujednačenost između formalnog i faktičkog položaja koji investitori uživaju u međunarodnom pravnom poretku. Formalno, strani investitori se uklapaju u definiciju nedržavnih aktera. Faktički, privatne multinacionalne korporacije sada su aktivni učesnici $u$ evoluciji međunarodnog javnog prava. ${ }^{134}$

Stoga smatramo da ovlašćenja investitora demonstrirana $\mathrm{u}$ prethodnim poglavljima, a koja se radi preglednosti mogu podeliti na:

1. ovlašćenja direktnog pregovaranja i zaključivanja internacionalizovanih ugovora;

2. ovlašćenja direktnog pravnog oblikovanja sadržine ugovornih odredbi;

3. prava da se podnese tužbeni zahtev protiv države izabranom međunarodnom arbitražnom tribunalu;

4. direktan uticaj na sadržinu i evoluciju međunarodnog investicionog prava;

5. njihov snažan ekonomski uticaj $u$ međunarodnom pravu i međunarodnim odnosima,

mogu poslužiti kao plodno tlo za dalji razvoj teorije njihovog ograničenog subjektiviteta.

${ }^{133}$ Vanja Pavićević, „Reforma bilateralnih investicionih sporazuma - od krize legitimiteta do instrumenta socijalne i ekološke pravde“" u Strane investicije u Srbiji - novi pogledi, Sanja Jelisavac Trošić, (ur.), Institut za međunarodnu politiku i privredu, Beograd, 2019, str. 201.

${ }^{134}$ Christian N. Okeke, Controversial Subjects of Contemporary International Law - an examination of the new entitites of international law and their treaty-making capacity, op. cit., p. 3. 


\section{ZAKLJUČNA RAZMATRANJA}

Međunarodnopravni poredak neretko ostaje slep na faktički, rastući uticaj određenih nedržavnih aktera, ostavljajući mesta različitim tumačenjima i pravnoj nesigurnosti. Pitanje međunarodnopravnog subjektiviteta i prateće odgovornosti ne uspeva uvek da uhvati korak sa dinamičnim nitima međunarodnih odnosa. Tradicionalno se uzima kao aksiom da su države dominantni i paradigmatični akteri $u$ međunarodnom pravu, ali i međunarodnim odnosima, dok se nedržavni akteri neretko definišu kao strano telo (Fremdkörper), koje se u najboljem slučaju ne može lako prilagoditi postojećim konceptualnim okvirima, a koje je, u najgorem slučaju, nevažno za disciplinarnu analizu. ${ }^{135}$ Naravno, deo doktrine izražava određenu skeptičnost kada je u pitanju koncept stepenovanja subjektiviteta, ne prihvatajući mogućnost stepenovanja međunarodnopravne ličnosti. ${ }^{136}$

Ostaje otvoreno pitanje da li je donekle promenljiv kriterijum subjektiviteta, opisan u prvom poglavlju, pogodan da precizno locira nedržavne aktere $u$ međunarodnopravnom poretku. $U$ toj pravnoj proceni, nije sigurno da bi klasična pravna metodologija bila dovoljna, budući da bi se ta procena vršila na osnovu kriterijuma koji tek treba da se definišu. ${ }^{137}$ Shodno tome, postaje očigledno da pitanje nedržavnih aktera prožima sve oblasti međunarodnog prava i ne može više biti ograničeno samo na puko pitanje subjektiviteta. ${ }^{138}$ Stoga, kada analiziramo uticaj određenog nedržavnog aktera, pored njegovog formalnog položaja, još je važnije ispitati njegov sveobuhvatni uticaj u međunarodnoj zajednici. Time se otvara put ka shvatanju da

135 "Chapter 17 - Concluding Observations", Non-State Actor Dynamics in International Law From Law-Takers to Law-Makers, Studies in International Law (Eds.), Cedric Ryngaert, Math Noortmann, August Reinisch, p. 369.

${ }^{136}$ Jean d'Aspremont, "Inclusive law-making and law-enforcement processes for an exclusive international legal system," in Participants in the International Legal System - Multiple Perspectives on non-state actors in International Law, (ed.) Jean d'Aspremont, Routledge Research in International Law, London, 2011, p. 433.

${ }^{137}$ Ibid., p. 429.

138 Ibid., p. 437. 
supstancijalni element pravne ličnosti nije stečen međunarodnim pravom, već samim činjenicama međunarodnog pravnog života. ${ }^{139}$

Navedena pravna nedorečenost posebno je izražena kod položaja multinacionalnih korporacija koje na teritoriji stranih država vrše strana ulaganja. Pitanje subjektiviteta stranih investitora jeste kontroverzno, i izaziva dosta oprečne stavove $u$ doktrini međunarodnog javnog i privatnog prava. Jedna škola mišljenja počiva na ideološkim osnovama, tj. težnji da se umanje moć i uticaj stranih korporacija, budući da već zauzimaju dominantnu poziciju u međunarodnim ekonomskim odnosima ${ }^{140}$ Dodatno, postoji i bojazan da bi se omogućavanjem sticanja subjekta međunarodnog prava stvorila platforma za legitimizovanje korporativnih praksi koje su ponekad smatrane eksploatacijskim. ${ }^{141}$

Cilj ovog istraživanja bio je da se sveobuhvatno prikaže položaj investitora $\mathrm{u}$ međunarodnom poretku, ali i njihov uticaj na široj međunarodnoj sceni. Takođe, analizirana je i dinamična veza između izvora međunarodnog investicionog prava i opštih pravnih pravila. Kao ishod takve interakcije, pravni položaj stranih investitora je složen i specifičan. Takva višeslojnost posebno dolazi do izražaja u međunarodnim investicionim sporovima, gde široka ovlašćenja koja investitori uživaju predstavljaju normativni začetak njihovog međunarodnopravnog subjektiviteta. Dodatno, ukazano je i na određene izazove sa kojima se međunarodno pravo i 'tradicionalni' pojam subjektiviteta suočavaju u susretu sa rastućom proliferacijom nedržavnih aktera. Ta 'zbunjenost' međunarodnog prava veoma je slikovito izražena stavom da 'sumrak bogova' zapravo i jeste stigao, ali da Minervina sova nije još poletela budući da teorija međunarodnog prava i dalje nije sustigla novu realnost. ${ }^{142}$

${ }^{139}$ Christian N. Okeke, Controversial Subjects of Contemporary International Law - an examination of the new entitites of international law and their treaty-making capacity, op. cit., p. 19.

${ }^{140}$ Patrick Dumberry, Érik Labelle-Eastaugh, "Non-state actors in international investment law: To be or not to be? The legal personality of non-state actors in international investment law", op. cit. p. 363.

${ }^{141}$ Ibid.

${ }^{142}$ Autorova primedba počiva na Kasezeovom slikovitom poređenju država, kao izvornih subjekata međunarodnog prava, sa bogovima, dodajući Hegelov primer 


\section{LITERATURA}

Monografije i naučni radovi:

Alvarez, José E., "Are Corporations "Subjects" of International Law?" Santa Clara Journal of International Law, 1 (2011), pp. 1-36.

Anthea Elizabeth Roberts, "Traditional and Modern Approaches to Customary International Law: A Reconciliation", The American Journal of International Law, Vol. 95. pp. 757-791.

Bhuta, Nehal, “The Role International Actors Other Than States can Play in the New World Order", in Realizing Utopia: The Future of International Law, (ed.) Antonio Cassese, Oxford University Press, USA, 2012. pp. 61-75.

Brownlie, Ian, The Rule of Law in International Affairs - International Law at the Fiftieth Anniversary of the United Nations, (General Course on Public International Law delivered at the Hague Academy of International Law to commemorate the fiftieth anniversary of the foundation of the United Nations), Martinus Nijhoff Publishers, The Hague, 1998.

Cantegreil, Julien, “The Audacity of the Texaco/Calasiatic Award: RenéJean Dupuy and the Internationalization of Foreign Investment Law", The European Journal of International Law, Vol. 22 no. 2, 2011, pp. 441-458.

Chechi, Alessandro, "Non-state actors and cultural heritage: friends or foes?", Anuario de la Facultad de Derecho de la Universidad Autónoma de Madrid, 19 (2015), pp. 457-479.

D'Aspremont, Jean, "Inclusive law-making and law-enforcement processes for an exclusive international legal system," in Participants in the International Legal System - Multiple Perspectives on non-state actors in International Law, (ed.) Jean d'Aspremont, Routledge Research in International Law, London, 2011, pp. 425-439.

D'Aspremont, Jean, "International Customary Investment Law: Story of a Paradox", in International Investment Law: The Sources of Rights and Obligations, (eds.) Tarcisio Gazzini, Eric Brabandere, Nijhoff International Investment Law (Book 1), The Netherlands, 2012, pp, 5-47. 
D'Aspremont, Jean, "Non-state actors in International Law: Oscillating Between Concepts and Dynamics" in Participants in the International Legal System - Multiple Perspectives on non-state actors in International Law, (ed.) Jean d'Aspremont, Routledge Research in International Law, London, 2011, pp. 1-21.

Dolzer, Rudolf, Schreuer, Christoph, Principles of International Investment Law, Oxford University Press, New York, 2008.

Đorđević, Stevan, Pravo međunarodnih ugovora, zbornik radova, Pravni fakultet Univerziteta u Beogradu, Beograd, 2011.

Dumberry, Patrick, "Are BITs Representing the "New" Customary International Law in International Investment Law?", Penn State International Law Review, Volume 28, Number 4, 2010, pp. 675-701.

Dumberry, Patrick, "International Investment Contracts", in International Investment Law: The Sources of Rights and Obligations, Nijhoff International Investment Law (Book1), The Netherlands, 2012, (eds.) Tarcisio Gazzini, Eric Brabandere, pp. 215-243.

Dumberry, Patrick, Labelle-Eastaugh, Érik, “Non-state actors in international investment law: To be or not to be? The legal personality of non-state actors in international investment law", in Participants in the International Legal System - Multiple Perspectives on non-state actors in International Law, (ed.), Jean d'Aspremont, Routledge Research in International Law, London, 2011, pp. 360-371.

Gazzini, Tarcisio, "Bilateral Investment Treaties", in International Investment Law: The Sources of Rights and Obligations, Nijhoff International Investment Law (Book1), The Netherlands, 2012, (eds.) Tarcisio Gazzini, Eric Brabandere, pp. 99-132.

Hegel, G.W.F., Osnovne crte filozofije prava, Svijetlost, Sarajevo, 1989, drugo izdanje.

Jovanović, Z. Marko, Odgovornost države za zaštitu stranih direktnih ulaganja, doktorska disertacija, Pravni fakultet Univerziteta $\mathrm{u}$ Beogradu, neobjavljeno.

Klabbers, Jan, International Law, Cambridge University Press, UK, 2017. 
Kreća, Milenko, Međunarodno javno pravo, Pravni fakultet Univerziteta u Beogradu, 2017.

Kreća, Milenko, Milisavljević, Bojan, Međunarodno pravo predstavljanja (diplomatsko i konzularno pravo), 2017, Pravni fakultet Univerziteta u Beogradu.

Lalive Pierre, Halonen, Laura, "On the availability of counterclaims in Investment Treaty Arbitration", in Rights of the Host State within the System of International Investment Protection, Czech Yearbook of International Law, Alexander J. Belohlavek, N. Rozehnalova (Eds.), 2011, Czech yearbook of International Law, pp. 141-156.

Levashova, Yulia, "The Accountability and Corporate Social Responsibility of Multinational Corporations for Transgressions in Host States through International Investment Law", Utrecht Law Review, Volume 14, Issue 2, 2018, pp. 40-55.

Malanczuk, Peter, "Multinational Enterprises and Treaty-Making - A Contribution to the Discussion on Non-State Actors and the "Subjects" of International Law", in Multilateral Treaty-Making: The Current Status of Challenges to and Reforms Needed in the International Legislative Process, (ed.)Vera Gowlland-Debbas, Nijhoff Law Specials Vol. 47, Springer Netherlands, 2000, pp. 45-72.

Mbengue, Makane Moïse, "National Legislation and Unilateral Acts of States", in International Investment Law: The Sources of Rights and Obligations, Nijhoff International Investment Law (Book 1), The Netherlands, 2012, (eds.) Tarcisio Gazzini, Eric Brabandere, pp. 183-213.

Milisavljević, Bojan, "Razvoj instituta diplomatske zaštite u međunarodnom pravu", Međunarodna politika, Institut za međunarodnu politiku i privredu, 2011, str. 80-93.

Muhvic, Davor, "Legal Personality as a Theoretical Approach to NonState Entities in International Law: The Example of Transnational Corporations", Pécs Journal of International and European Law, Centre for European Research and Education, 2017/I, pp. 7-18.

Nijman, Janne E., "Non-state actors and the international rule of law: Revisiting the 'realist theory' of international legal personality", in 
Non-State Actor Dynamics in International Law, From Law-Takers to LawMakers, (eds.) Math Noortmann, Cedric Ryngaertp, Ashate Publishing, 2010, pp. 91-124.

Nikolić, Andrea, „Inovativne klauzule afričkih bilateralnih investicionih ugovora", Identitetski preobražaj Srbije, Prilozi projektu 2018 kolektivna monografija, (ur.) Ivana Krstić, Maja Lukić Radović, Pravni fakultet Univerziteta u Beogradu, Beograd, 2019, str. 337-353.

Noortmann, Math, "The International Law Association and Non-State Actors: Professional network, public interest group or epistemic community?", in Participants in the International Legal System - Multiple Perspectives on non-state actors in International Law, (ed.) Jean d'Aspremont, Routledge Research in International Law, London, 2011. pp. 233-258.

Okeke, Christian N., Controversial Subjects of Contemporary International Law - an examination of the new entitites of international law and their treaty-making capacity, Rotterdam University Press, 1973.

Olmedo, Javier García, "Redefining the Position of the Investor in the International Legal Order and the Nature of Investment Treaty Rights: A Closer Look at the Relationship between Diplomatic Protection and Investor- State Arbitration", in Non-State Actors and International Obligations: Creation, Evolution and Enforcement, James Summers, Alex Gough (Eds.), Koninklijke Brill NV, Leiden, The Netherlands, 2018, pp. 158-176.

Pavićević, Vanja, „Reforma bilateralnih investicionih sporazuma - od krize legitimiteta do instrumenta socijalne i ekološke pravde“, $\mathrm{u}$ Strane investicije u Srbiji - novi pogledi, Sanja Jelisavac Trošić, (ur.), Institut za međunarodnu politiku i privredu, Beograd, 2019, str. 188-208.

Reisman, W. Michael, "The Future of International Investment Law and Arbitration", in Realizing Utopia: The Future of International Law, (ed.) Antonio Cassese, Oxford University Press, USA, 2012, pp. 275-286.

Ryngaert, Cedric, Noortmann, Math, Reinisch, August, “Chapter 17 Concluding Observations", Non-State Actor Dynamics in International 
Law From Law-Takers to Law-Makers, Studies in International Law, pp. 369-376.

Schill, Stephan W., "General Principles of Law and InternationaL Investment Law", in International Investment Law: The Sources of Rights and Obligations, Nijhoff International Investment Law (Book 1), The Netherlands, 2012, (eds.) Tarcisio Gazzini, Eric Brabandere, pp. 133-182. Shaw, Malcolm N., International Law, Cambridge University Press, USA, New York, Sixth edition, 2008.

Thirlway, High, The Sources of International Law, Oxford University Press, 2014.

\subsection{Dokumenti:}

Bečka konvencija o ugovornom pravu, dostupno na https:/ / treaties.un. org/doc/Publication/UNTS/Volume\%201155/volume-1155-I18232-English.pdf

Montevideo konvencija o pravima i dužnostima država, "Convention on Rights and Duties of States", Art. 1, dostupno na https:// www.oas.org/juridico/english/treaties/a-40.html.

Statistika o zaključenim BIT-ovima je dostupna na https://investment policy.unctad.org/international-investment-agreements

The Texaco Overseas Petroleum Company and California Asiatic Oil Company v. The Government of the Libyan Arab Republic, dostupno na https://www.trans-lex.org/261700/_/texaco-overseas-petroleumcompany-v-the-government-of-the-libyan-arab-republic-yca-1979-at177-et-seq-/

Urbaser S.A. and Consorcio de Aguas Bilbao Bizkaia, Bilbao Biskaia Ur Partzuergoa v. The Argentine Republic, ICSID Case No. ARB/07/26, 2016, par. 1194-1195, p. 316-317, dostupno na https://www.italaw. com/sites/default/files/case-documents/italaw8136_1.pdf

Vodeći principi za jednostrane akte država koje stvaraju određena prava i obaveze "Guiding Principles applicable to unilateral declarations of States capable of creating legal obligations, with commentaries 
thereto", 2006, dostupno na https://legal.un.org/docs/?symbol= A/CN.4/L.703

Permanent Court of International Justice, Case concerning the payment of various Serbian loans issued in France, 1929, p. 41, dostupno na https://www.icj-cij.org/files/permanent-court-of-international justice/serie_A/A_20/62_Emprunts_Serbes_Arret.pdf

Draft conclusions on identification of customary international law, with commentaries, 2018, https:/ / legal.un.org/ilc/texts/1_13.shtml

Energy charter treaty, dostupno na: https://www.energycharter.org/ process/energy-charter-treaty-1994/energy-charter-treaty/

European Court of Human Rights, Grand Chamber Judgment Kafkaris v. Cyprus, https://hudoc.echr.coe.int/eng-press\#\{“itemid":["0032266462-2424484"]\}

ICSID - International Centre for Settlement of Investment Disputes, dostupno na https://icsid.worldbank.org/en/

Izveštaj američkog nacionalnog obaveštajnog saveta, "Global Trends 2025: A Transformed World", National Intelligence, Council USA, dostupno na https://www.dni.gov/files/documents/Newsroom/ Reports\%20and\%20Pubs/2025_Global_Trends_Final_Report.pdf

North American Free Trade Agreement - NAFTA, dostupno na: https://www.nafta-sec-alena.org/Home/Texts-of-theAgreement/North-American-Free-Trade-Agreement

Izveštaj Komiteta za nedržavne aktere Udruženja za međunarodno pravo, First report of the committee "Non-state actors in international law: aims, approach and scope of project and legal issues", ILA International Law Association, The Hague Conference, 2010.

Zakon o stranim ulaganjima Republike Srbije https:/ / www.paragraf.rs/ propisi/zakon_o_ulaganjima.html Službeni glasnik RS, br. 89/2015 i 95/2018.

Reparation for injuries suffered in the service of the United Nations, Advisory Opinion: ICJ, April 11th 1949, p. 178, dostupno na https:// www.icjcij.org/files/case-related/4/004-19490411-ADV-01-00-EN.pdf. 


\section{INFLUENCE OF INVESTORS AS NON-STATE ACTORS IN INTERNATIONAL LAW}

Abstract: The international legal order in the 21st century is increasingly reminiscent of a kaleidoscope composed of many non-state actors influencing the dynamics of international relations through various activities. From the position of non-governmental organizations, individuals and minorities - indigenous peoples, through terrorist groups to multinational companies, there is no area of international law in which non-state actors, to a greater or lesser extent, have not influenced the creation, development or application of legal norms. Nevertheless, the role of non-state actors appears to be most visible in the area of international investment law, as reflected in the growing influence of foreign investors. Their position provokes a lot of controversy in international law, primarily due to the specific dispute resolution mechanism that allows the investor to file a lawsuit with the selected arbitral tribunal directly against the host country. In this way, despite the formal lack of character of a subject in international law, the investor manages to actually equate his position in a particular dispute with the state. Additionally, the legal nature of the socalled "Internationalized agreements" provides opportunities for different interpretations - can investors based on such agreements enjoy not only the status of an object but, to a certain extent, also a subject of international law? In this paper, the author will examine the sources of international investment law, the position of investors in resolving investment disputes, as well as the possible difference between the formal and factual position that investors in the international legal order enjoy.

Keywords: non-state actors, investors, multinational companies, international legal subjectivity, arbitral dispute resolution, investment disputes, international investment law. 